\title{
MORFOLOGIA DO RELEVO E FORMAÇÕES SUPERFICIAIS DO RIBEIRÃO DO BAÚ, SÃO BENTO DO SAPUCAÍ, SP
}

\section{Rosana Dias ARANHA}

Rosely Pacheco DIAS FERREIRA

\begin{abstract}
RESUMO
Este trabalho apresenta os resultados da cartografia morfológica realizada na bacia do ribeirão do Baú, município de São Bento do Sapucaí, SP. Esta bacia abrange um trecho da escarpa erosiva do Planalto de Campos do Jordão, compartimento morfoestrutural da Serra da Mantiqueira Oriental. A carta morfológica da bacia do Baú (1:50.000), construída a partir de fotografias-aéreas (1:25.000), considerou na sua concepção e orientação de legenda, os princípios estabelecidos pela RCP.77, do CNRS, França, para a cartografia geomorfológica de detalhe. Ênfase maior foi dada para a representação morfográfica, tendo em vista a diversidade e riqueza das feições e modelado do relevo. A correlação entre a carta morfológica e as bases hipsométrica e clinográfica, possibilitou a individualização de 7 compartimentos morfológicos para a bacia do ribeirão do Baú registrados em cartograma na escala 1:50.000. Dentre as características morfológicas e morfométricas da bacia, destacamse as formas de relevo que mostram claro condicionamento estrutural, como cristas e vertentes com facetas triangulares e os divisores rochosos e escarpados do complexo Baú-Bauzinho-Ana Chata. Os interflúvios convexos são recortados por vales encaixados, com zonas estranguladas (soleiras) apresentando afloramentos rochosos e cachoeiras. Anfiteatros de erosão com diferentes tamanhos e em várias posições altimétricas modelam as vertentes, definindo setores nas cabeceiras com morfologia característica (superfícies rugosas), ligadas a movimentos de massa. Outra feição particular são as concavidades que aparecem nas vertentes e patamares (ombreiras) cartografadas como depressões e concavidades com patamar. Para destacar as características morfológicas desses setores e as feições das vertentes, foi elaborada uma carta morfológica na escala 1:10.000, a partir da interpretação de fotografias aéreas na escala 1:8.000, complementada pela investigação dos solos através de tradagens e perfis. Os resultados mostraram que as superfícies rugosas correspondem a depósitos relacionados à evolução dos anfiteatros, enquanto as depressões e concavidades com patamar estão relacionadas à erosão geoquímica, que se desenvolve no maciço rochoso, a partir de fraturas na rocha. A gênese dessas feições morfológicas é explicada a partir de modelos propostos na literatura sobre a evolução das vertentes nos domínios montanhosos do Brasil de sudeste.
\end{abstract}

Palavras-chave: Cartografia morfológica; Compartimentação do relevo; Morfologia de vertentes; Pedra do Baú; Planalto de Campos do Jordão; Serra da Mantiqueira. 
This paper presents the results of a morphological cartographic study carried out in the Ribeirão do Baú basin, São Bento do Sapucaí municipality, State of São Paulo Brazil. This basin corresponds to a sector of the erosive escarpment of the Campos do Jordão plateau, which is a morphostructural compartment of the eastern part of the Mantiqueira Mountain Ridge. The legend design of the 1:50,000-scale morphological map of the Ribeirão do Baú basin, preliminarily prepared from 1:25,000-scale aerial photographs, took into account the principles established by RCP.77, CNRS, France, for detailed geomorphological cartography. Greater emphasis was given to the morphographic representation, having in mind the diversity and richness of landform features. The correlation between the morphological, slope, and hypsometric maps allowed the individualization of seven morphological compartments for the Ribeirão do Baú basin at the 1:50,000 scale. Among the morphological and morphometric characteristics of the basin, landforms clearly controlled by structural features are represented by ridges and slopes with triangular facets, and the rocky scarped divisors of the Baú-Bauzinho-Ana Chata complex. The convex interfluves are cut by encased valleys, with strangled areas (sills) and rocky outcrops and waterfalls. Erosive amphitheaters, with different sizes and at various levels, model the hillslopes and define zones in the headwaters with specific morphology (rough surfaces) connected to mass movements. Other particular features are the concavities that appear on the hillslopes and terraces, mapped as depressions and concavities with steps. In order to highlight the morphological characteristics of these zones and the hillslope features, a 1:10.000-scale morphological map was prepared from the interpretation of 1:8.000-scale aerial photographs, and complemented by soil investigation via auger surveying and trenching. The results showed that the rough surfaces correspond to deposits related to the erosion of amphitheaters, whereas the depressions and concavities with steps are related to geochemical erosion, which develops from fractures in the subjacent rock mass. The genesis of these morphological features is explained on the basis of models proposed in the literature for hillslope evolution in mountainous areas of Southeastern Brazil.

Keywords: Morphological cartography; Relief compartmentation; Slope morphology; Pedra do Baú; Campos do Jordão plateau; Mantiqueira Ridge.

\section{INTRODUÇÃO}

A cartografia geomorfológica é uma das formas de estudo do relevo mais tradicionais. Segundo DONÉ (1981), "nunca houve pesquisa geomorfológica sem representação cartográfica, mesmo sendo em forma de croquis" (p. 85). Contudo, a cartografia geomorfológica passou a ser mais sistematizada e discutida apenas após o $18^{\circ}$ Congresso Internacional de Geógrafos da UGI, no Rio de Janeiro, em 1956. A partir deste evento, cresceu o número de publicações sobre esta temática, culminando na criação da Subcomissão para o Mapeamento Geomorfológico da União Internacional de Geógrafos em 1958, no Congresso de Estocolmo. Em consequência disso, surgiram propostas sobre a padronização de legendas e a classificação taxonômica.

Resgatando os trabalhos clássicos de Passarge e Gehne, ambos de 1912, no sentido de definir princípios para a cartografia geomorfológica, TRICART (1965) estabeleceu que no mapeamento geomorfológico de detalhe deveriam ser incluídos os seguintes dados:

- morfométricos: referem-se ao tamanho das formas; 
- morfológicos ou morfográficos: referem-se à representação qualitativa das formas do relevo;

- morfogenéticos: dizem respeito à origem das formas representadas;

- cronológicos: correlacionam as formas com a evolução geomorfológica regional - devem apresentar a idade das formas, diferenciando as formas derivadas de processos pretéritos dos atuais.

Embora exista toda essa sistemática quanto ao conteúdo das cartas geomorfológicas, sabe-se que muitas vezes o mapeamento do relevo contém apenas alguns desses itens elencados por Tricart, como no caso das cartas morfológicas. Estas cartas são produtos onde apenas os dados morfométricos e morfográficos são representados. Embora possuam um caráter descritivo, esses dados são importantes, pois fornecem indícios de alguns processos morfogenéticos (FURQUIM 1997).

A carta morfológica é base para muitos estudos geomorfológicos. É um documento de referência, pois mostra um quadro a partir do qual é possível compreender a organização espacial das formas, sua diversidade e densidade, orientando tanto no entendimento da evolução da paisagem, quanto na delimitação de áreas que necessitam de investigação mais detalhada. Ressaltando a importância do enfoque deste mapeamento, DEMEK (1967) afirmou que um mapa geomorfológico de detalhe deve ter como principal conteúdo as formas de relevo concretas e suas partes. Nesse contexto, vários encontros foram realizados para discutir $\mathrm{e}$ estabelecer os princípios gerais do mapeamento geomorfológico, além de propor uma legenda unificada que permitisse uma melhor comparação entre os mapas que estavam sendo elaborados em várias partes do mundo.

O desenvolvimento da cartografia geomorfológica, juntamente com o aprimoramento dos materiais cartográficos e aerofotográficos, levou a um detalhamento das representações das formas do relevo, tornando os mapas geomorfológicos cada vez mais complexos e de difícil leitura. Isso foi gerado pela complexidade das informações que o mapa geomorfológico deve conter (morfologia, morfometria, morfogênese e morfocronologia), o que leva à uma multiplicidade de símbolos e cores.

Várias legendas geomorfológicas vêm sendo utilizadas, e a tentativa de uma padronização universal, como apresentada no Manual de Mapeamento Geomorfológico de Detalhe (DEMEK 1972), não foi amplamente adotada. A Cartografia Geomorfológica Francesa, divulgada pelo CNRS em 1971 no documento normativo -
RCP.77 (TRICART 1972), para as cartas geomorfológicas de detalhe da França (1:20.000; 1:25.000 e 1:50.000), foi adotada pelos pesquisadores franceses em programas de pesquisa na França e em países que tradicionalmente estavam filiados à escola francesa de geomorfologia.

Um dos exemplos da aplicação e avaliação da proposta francesa em meio tropical foi a experiência levada a efeito pelo Laboratório de Pedologia e Sedimentologia do Instituto de Geografia da Universidade de São Paulo, por meio de um convênio com o Centre de Géomorphologie $d u$ $C N R S$, que resultou na publicação em 1978 das cartas geomorfológicas e de formações superficiais das regiões de Marília (1:100.000), São Pedro (1:50.000) e Parateí (1:25.000), no estado de São Paulo, e Lagoa Santa (1:50.000), em Minas Gerais.

Essa experiência pioneira de aplicação da legenda francesa no tropical úmido brasileiro demandou adaptações na proposta original, em função das diferenças entre o contexto climático e geotectônico da França e do Brasil. Contudo, essas modificações não constituíram um problema, pois permitiram uma abertura para outras possibilidades de representações e discussões. Nesse sentido, salienta-se que o objeto a ser perseguido é o método, pois a técnica e a escolha das representações gráficas devem estar ajustadas em função da escala de abordagem.

Assim, este trabalho tem como objetivo estudar as formas de relevo e os materiais da bacia do ribeirão do Baú, situada no município de São Bento do Sapucaí (SP), tendo como referência metodológica os pressupostos da cartografia geomorfológica francesa, com ênfase na representação morfológica. Justifica-se, ainda, pela necessidade de estudos geomorfológicos de detalhe neste setor de paisagens serranas da Mantiqueira Ocidental.

\section{CARACTERIZAÇÃO DA ÁREA DE ESTUDO}

A área de estudo (Figura 1) está inserida na morfoestrutura do Cinturão Orogênico do Atlântico (ROSS \& MOROZ 1997), que tem a sua gênese ligada a vários episódios de dobramentos, metamorfismos regionais, falhamentos e extensas intrusões. Os processos orogênicos estão ligados a várias fases do Pré-Cambriano, especialmente ao chamado Ciclo Brasiliano (BRITO NEVES et al. 2014), enquanto os epirogenéticos e deformacionais, pós-cretáceos estão relacionados com o soerguimento e reativação tectônica da Plataforma Sul-Americana, que produziu escarpas como as 
serras do Mar e da Mantiqueira e fossas tectônicas, como o vale do rio Paraíba do Sul (ALMEIDA \& CARNEIRO 1998, RICCOMINI et al. 2004). Conforme ALMEIDA (2018), a área insere-se na província do Planalto Atlântico, zona do Planalto de Campos do Jordão, que constitui um planalto tectonicamente alçado, de estrutura cristalina, com limites essencialmente tectônicos, determinados por falhas transcorrentes com direção ENE (Falha do Paiol Grande ou de São Bento do Sapucaí, a noroeste, e a Zona de Cisalhamento de Jundiuvira, a sudeste).
A bacia do ribeirão do Baú caracteriza-se como uma importante frente de dissecação do Planalto de Campos do Jordão, sendo responsável, juntamente com outros afluentes da margem direita do rio Sapucaí-Mirim, pelo festonamento da escarpa sudoeste deste planalto e pela individualização dos Planaltos de Campos do Jordão e o de Camanducaia (Figura 1). A borda festonada do planalto constitui o divisor de águas das bacias do Sapucaí e Sapucaí-Mirim. Nas sub-bacias do Sapucaí-Mirim, o relevo é mais dissecado com maior entalhamento dos vales e declividades mais elevadas, enquanto no setor do Alto Sapucaí, bacia

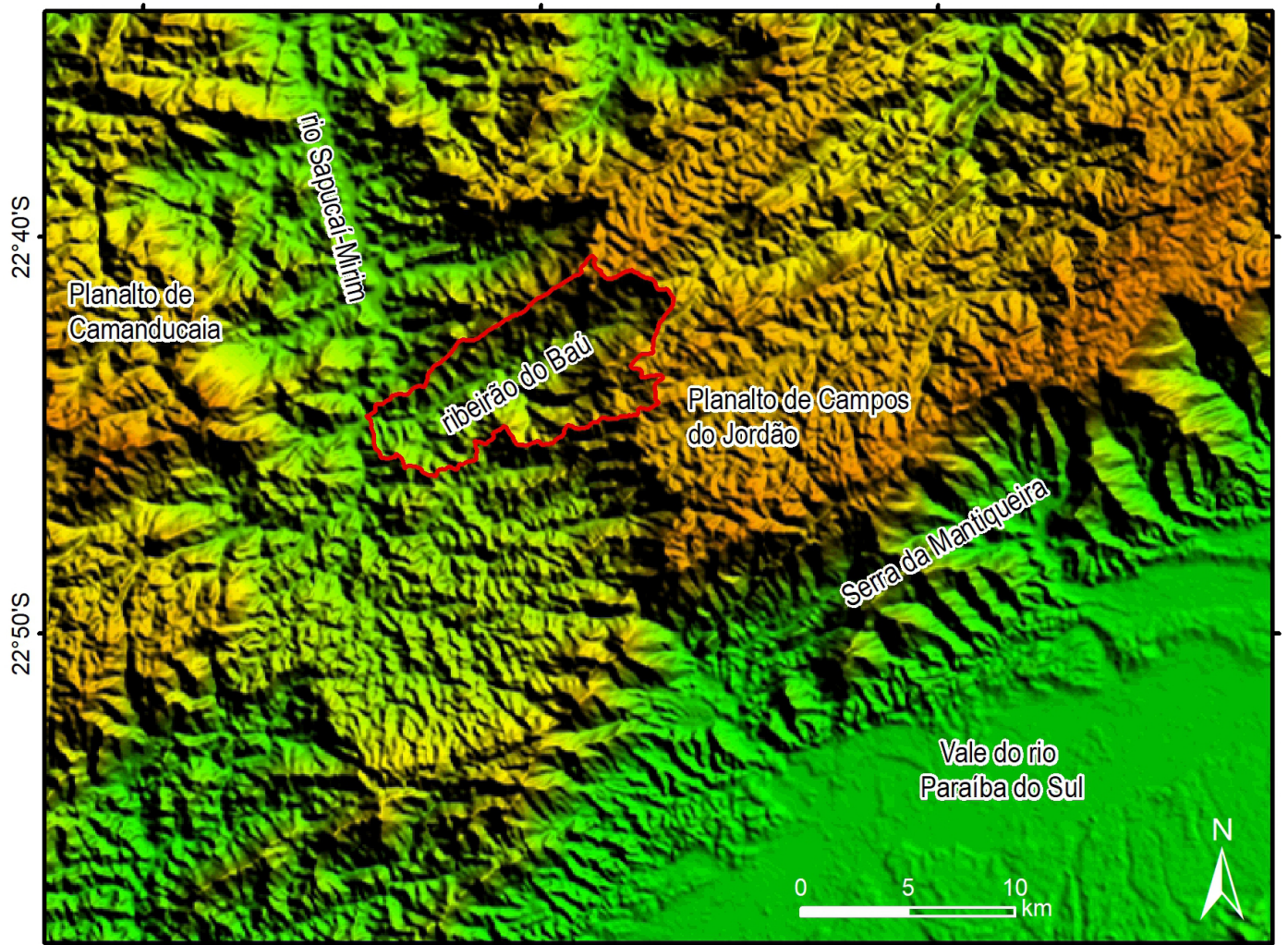

$45^{\circ} 50^{\prime} \mathrm{W}$

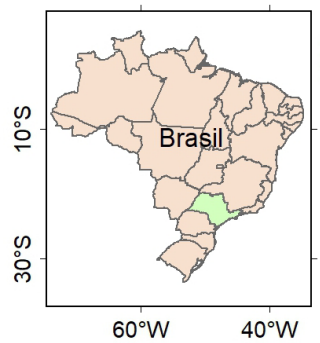

$45^{\circ} 40^{\prime} \mathrm{W}$

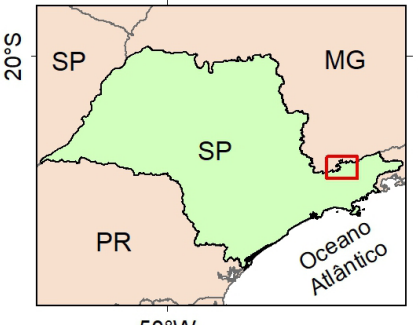

$45^{\circ} 30^{\prime} \mathrm{W}$

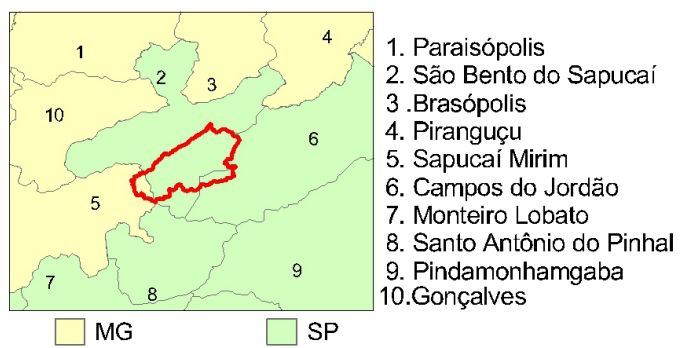

FIGURA 1 - Localização da área de estudo. Mapa de sombreamento de relevo gerado a partir de imagens SRTM/NASA. 
do ribeirão Marmelos, domina a paisagem típica dos altos campos (MODENESI 1988), com entalhes menos profundos e amplitudes altimétricas menores.

Os interflúvios da margem direita da bacia, incluindo o conjunto de cristas rochosas, denominado de Complexo da Pedra do Baú, constituem-se de (granada)-biotita-hornblenda gnaisses bandados estromáticos, dobrados e redobrados, transpostos e milonitizados (HIRUMA \& TEIXEIRA 2013). As vertentes e os interflúvios da margem esquerda constituem-se de rochas (granada)-biotita-hornblenda gnaisses protomiloníticos bandados, estromáticos, e apresentam frequentemente intercalações de ortoquartzitos, anfibolitos, hornblenda gnaisses e rochas calciossilicatadas. De uma maneira geral, não foi observada uma variação significativa de litologia entre as vertentes da bacia do Baú; portanto, algumas diferenças analisadas ao longo da bacia, como por exemplo, a presença de interflúvios em forma de cristas em apenas um dos limites (Complexo da Pedra do Baú) está relacionada, principalmente, ao controle tectônico e estrutural e não litológico, conforme salientado por HIRUMA \& TEIXEIRA (2013).

Com relação aos aspectos pedológicos, segundo IAC (1999) e ROSSI (2017), na bacia do Baú predominam Argissolos Vermelho-Amarelo distróficos com A moderado e proeminente, e Argissolos Vermelho-Amarelo eutróficos, ambos de textura média/argilosa e argilosa.

\section{PROCEDIMENTOS TÉCNICO-OPERACIONAIS}

A carta morfológica, escala 1:50.000 (Anexo 1) foi elaborada a partir da restituição da rede de drenagem e das formas de relevo da bacia de ribeirão do Baú obtida a partir da fotointerpretação das fotografias aéreas do IAC (1:25.000, ano 1962, fotos: 7281 a 7285,7331 a 7339,7343 a 7347). Adotou-se para a restituição a orientação descrita por RICCI \& PETRI (1965), que propõem o exame estereoscópio de toda a área da foto central, de um conjunto de três fotografias aéreas sucessivas ("stereo-triplet") de uma mesma faixa de vôo, com recobrimento longitudinal obrigatoriamente superior a $50 \%$, como mostra a figura 2 .

Após a definição das fotos-centrais, iniciou-se a leitura dos elementos das fotografias. Primeiramente foram mapeados os cursos d'água e as formas do relevo, sem nenhuma legenda pré-estabelecida. As formas foram mapeadas con- forme se mostravam na paisagem, valorizando sua geometria e mantendo as proporções de tamanho. A partir deste primeiro esboço, foi elaborado um inventário das formas mapeadas (morfografia), possibilitando o conhecimento da diversidade morfológica da bacia e sua distribuição espacial.

No mapeamento morfológico da bacia do ribeirão do Baú (1:50.000) usou-se como diretriz a legenda proposta na RCP.77 do CNRS - França. Essa legenda já havia sido apresentada, discutida e testada, durante o Projeto Franco-Brasileiro "Estudo e Cartografia das Formações Superficiais" (QUEIROZ NETO \& JOURNAUX 1978), quando da elaboração das cartas geomorfológicas de Marília, São Pedro, Vale do Parateí e do Carste de Lagoa Santa. Trata-se de uma proposta com forte atributo genético, privilegiando informações relativas à gênese das formas, sua distribuição e arranjo, a interação com outras formas e depósitos correlativos, entre outros.

Nesta legenda, cada táxon, ou unidade geomorfológica, é definido através do conjunto de vários elementos, como: localização, contexto estrutural e morfogenético, formações superficiais e características morfológicas das formas. As cores utilizadas são atribuídas à morfogênese, domínio morfoclimático e ao contexto estrutural. As variações de intensidade da cor indicam cronologia, sendo que as mais intensas correspondem às formas mais recentes.

$\mathrm{Na}$ organização desta legenda, as formas mapeadas foram agrupadas em três conjuntos: formas estruturais, formas dissecadas pela ação fluvial e formas ligadas a movimentos de massa. Este agrupamento é decorrente da interpretação

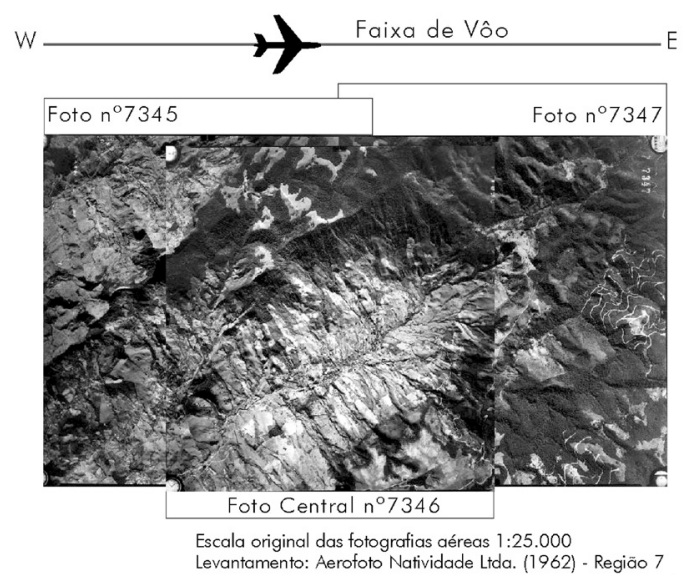

FIGURA 2 - Esquema do sistema "stereo-triplet", proposto por RICCI \& PETRI (1965). 
genética a partir das características das formas de relevo e de suas formações superficiais, cujas características fundamentais foram descritas em campo. Visando sistematizar a legenda, foi elaborado um quadro-síntese (Quadro 1) com as seguintes informações: nome da forma, descrição conceitual, visão vertical (foto-aérea), visão oblíqua (fotos de campo) e a representação utilizada no mapeamento.

Vale enfatizar que a escolha das cores utilizadas na legenda morfológica foi uma opção técnica, visando facilitar a leitura e a análise, não seguindo, portanto, as indicações da cartografia geomorfológica de detalhe, que tem na cor uma variável de cunho estrutural/litológico e genético. Sendo assim, neste mapeamento a cor teve o intuito de destacar as ocorrências morfológicas de modo a visualizar melhor as suas frequências, magnitudes, encadeamento, geração de formas embutidas, hierarquia e zonas.

A partir do mapeamento morfológico da bacia do ribeirão do Baú (1:50.000) e a sua correlação com as cartas hipsométrica e clinográfica (Anexo 2), foi elaborado uma carta de compartimentação morfológica. Os compartimentos foram definidos em função do estabelecimento de áreas (manchas homogêneas) que apresentavam características morfométricas (altimetria e declividade) e morfológicas semelhantes. A legenda utilizada nessa carta sistematiza as principais características de cada compartimento, apresentando, além do significado das simbologias e cores empregadas, os dados morfométricos (intervalos de altitudes e de declividades), as informações de litologia e formas de relevo predominantes, juntamente com perfis topográficos dos tipos de interflúvios de cada compartimento.

Além disso, procurando uma maior compreensão e detalhamento das formas mapeadas na carta morfológica (1:50.000), produziu-se uma carta morfológica de detalhe (1:10.000, Anexo 3). Para este mapeamento foi escolhido o setor da bacia (Baú do Centro) que apresentava um número significativo das formas mais representativas. Esta carta foi elaborada a partir de fotografias-aéreas do IBC - 1982 (1:8.000) adotando os mesmos princípios da fotointerpretação já descritos para o mapeamento morfológico da Bacia do Baú. A legenda utili-

QUADRO 1 - Sistematização da legenda do mapeamento morfológico na escala 1:50.000.

HIDROGRAFIA

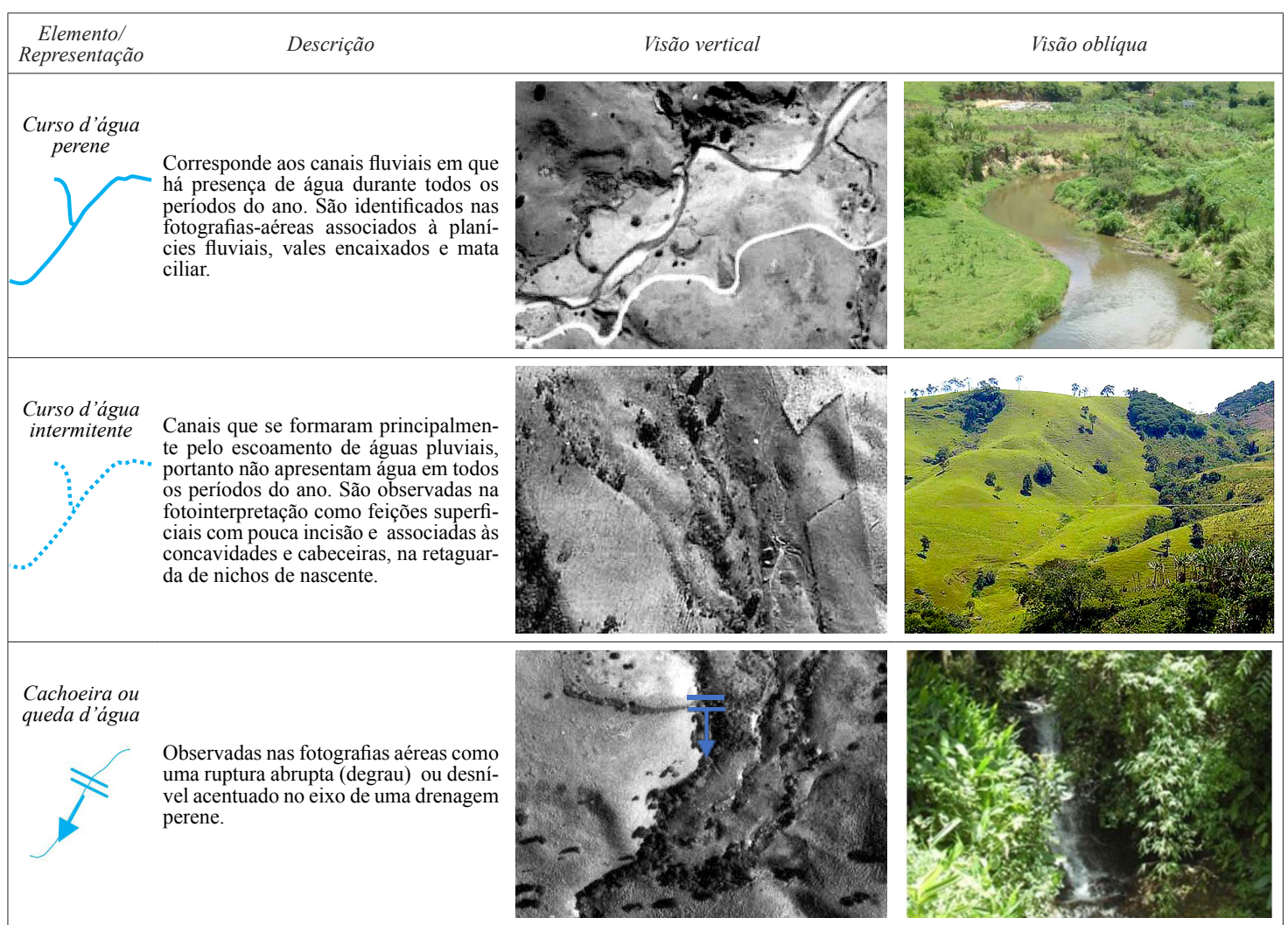


QUADRO 1 - (cont.) Sistematização da legenda do mapeamento morfológicco na escala 1:50.000.

FORMAS ESTRUTURAIS

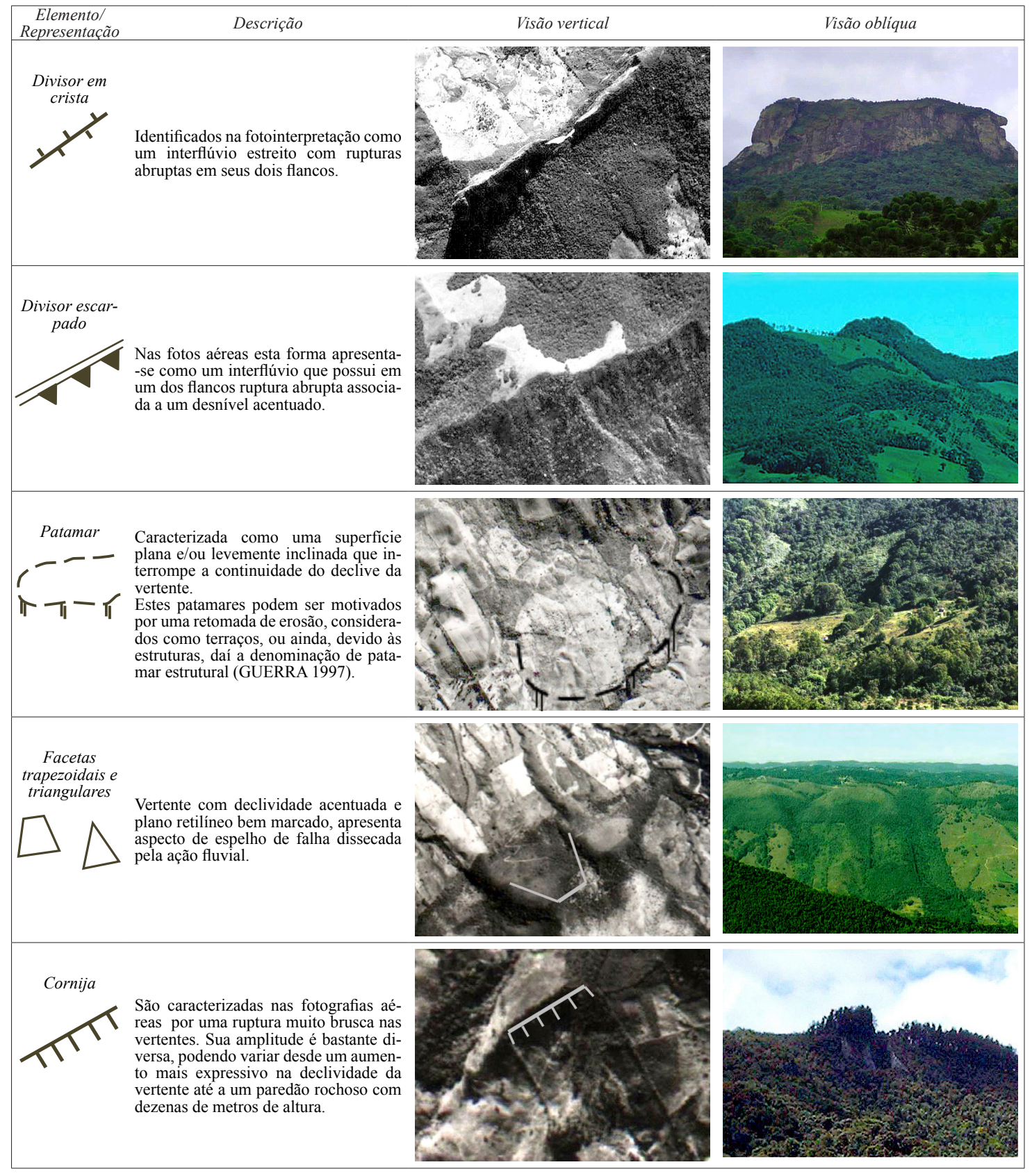

FORMAS DISSECADAS PELA AÇÃO FLUVIAL

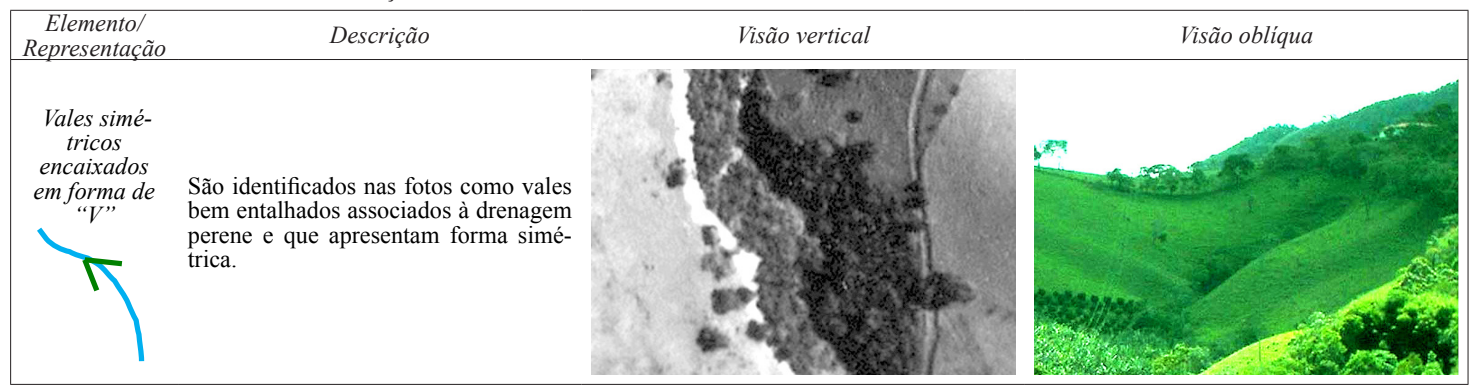


QUADRO 1 - (cont.) Sistematização da legenda do mapeamento morfológico na escala 1:50.000.

FORMAS DISSECADAS PELA AÇÃO FLUVIAL (cont.)

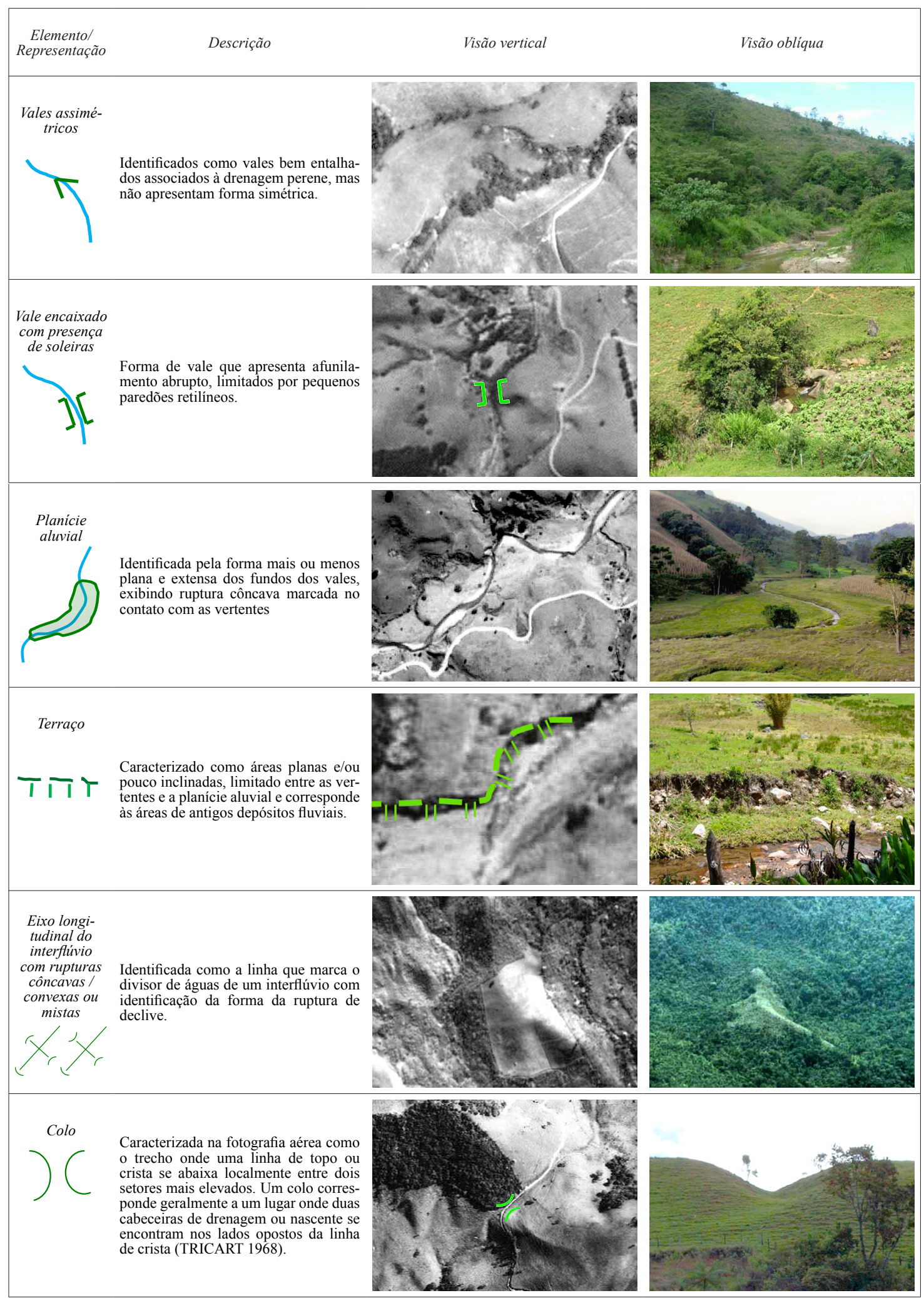


QUADRO 1 - (cont.) Sistematização da legenda do mapeamento morfológico na escala 1:50.000.

FORMAS DISSECADAS PELA AÇÃO FLUVIAL (cont.)

\begin{tabular}{|c|c|c|c|}
\hline $\begin{array}{c}\text { Elemento/ } \\
\text { Representação }\end{array}$ & Descrição & Visão vertical \\
\hline $\begin{array}{l}\text { Identificada na foto-aérea como o setor } \\
\text { mais elevado do interflúvio, com for- } \\
\text { mas predominantemente arredondadas } \\
\text { e delimitada totalmente por uma ruptu- } \\
\text { ra convexa. }\end{array}$ \\
$\begin{array}{l}\text { Ruptura } \\
\text { convexa }\end{array}$ \\
$\begin{array}{l}\text { Linha que marca a ruptura convexa de } \\
\text { declividade ao longo de uma vertente. }\end{array}$
\end{tabular}

FORMAS LIGADAS À MOVIMENTOS DE MASSA E/OU EROSÃO GEOQUÍMICA

\begin{tabular}{|c|c|c|c|}
\hline $\begin{array}{c}\text { Elemento/ } \\
\text { Representação }\end{array}$ & Descrição & Visão vertical & Visão oblíqua \\
\hline $\begin{array}{c}\text { Concavidade } \\
\text { ampla } \\
1 \\
1\end{array}$ & $\begin{array}{l}\text { Concavidade ampla com canais inter- } \\
\text { mitentes instalados em seu interior. } \\
\text { Pode estar associada a outras cicatri- } \\
\text { zes de menor amplitude. Essas áreas } \\
\text { foram mapeadas utilizando seu limite } \\
\text { superior. As paredes internas desta } \\
\text { concavidade variam bastante quanto à } \\
\text { declividade. }\end{array}$ & & \\
\hline 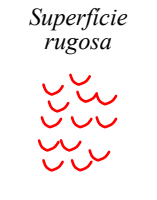 & $\begin{array}{l}\text { Identificada na fotografia aérea pelo } \\
\text { aspecto rugoso da sua superfície; apre- } \\
\text { senta um patamar com plano inclinado } \\
\text { e irregularidades na superfície. Presen- } \\
\text { ça de fluxos intermitentes difusos em } \\
\text { seu interior. }\end{array}$ & & \\
\hline $\begin{array}{l}\text { Cicatriz de } \\
\text { escorrega- } \\
\text { mento }\end{array}$ & & & \\
\hline $\begin{array}{l}\text { Cicatriz de es- } \\
\text { corregamento } \\
\text { com patamar }\end{array}$ & $\begin{array}{l}\text { Cicatrizes que apresentam uma con- } \\
\text { cavidade bem delimitada em forma de } \\
\text { concha. As paredes internas na maioria } \\
\text { dos casos são côncavas. A peculiarida- } \\
\text { de desta forma é a presença de um pe- } \\
\text { queno patamar, relativamente plano, na } \\
\text { parte inferior desta concavidade. } \\
\text { Delimitou-se toda a borda superior des- } \\
\text { ta cicatriz pontilhando o contato cônca- } \\
\text { vo com o patamar. }\end{array}$ & & \\
\hline
\end{tabular}


QUADRO 1 - (cont.) Sistematização da legenda do mapeamento morfológico na escala 1:50.000. FORMAS LIGADAS À MOVIMENTOS DE MASSA E/OU EROSÃO GEOQUÍMICA (cont.)

\begin{tabular}{|lll|}
\hline $\begin{array}{c}\text { Elemento/ } \\
\text { Representação }\end{array}$ & Descrição & Visão vertical obliqua \\
\hline Depressão & $\begin{array}{l}\text { Fotointerpretada como uma concavida- } \\
\text { de de geometria circular sem conecti- } \\
\text { idade aparente com canais perenes ou } \\
\text { intermitentes. }\end{array}$ &
\end{tabular}

FORMAS EROSIVAS

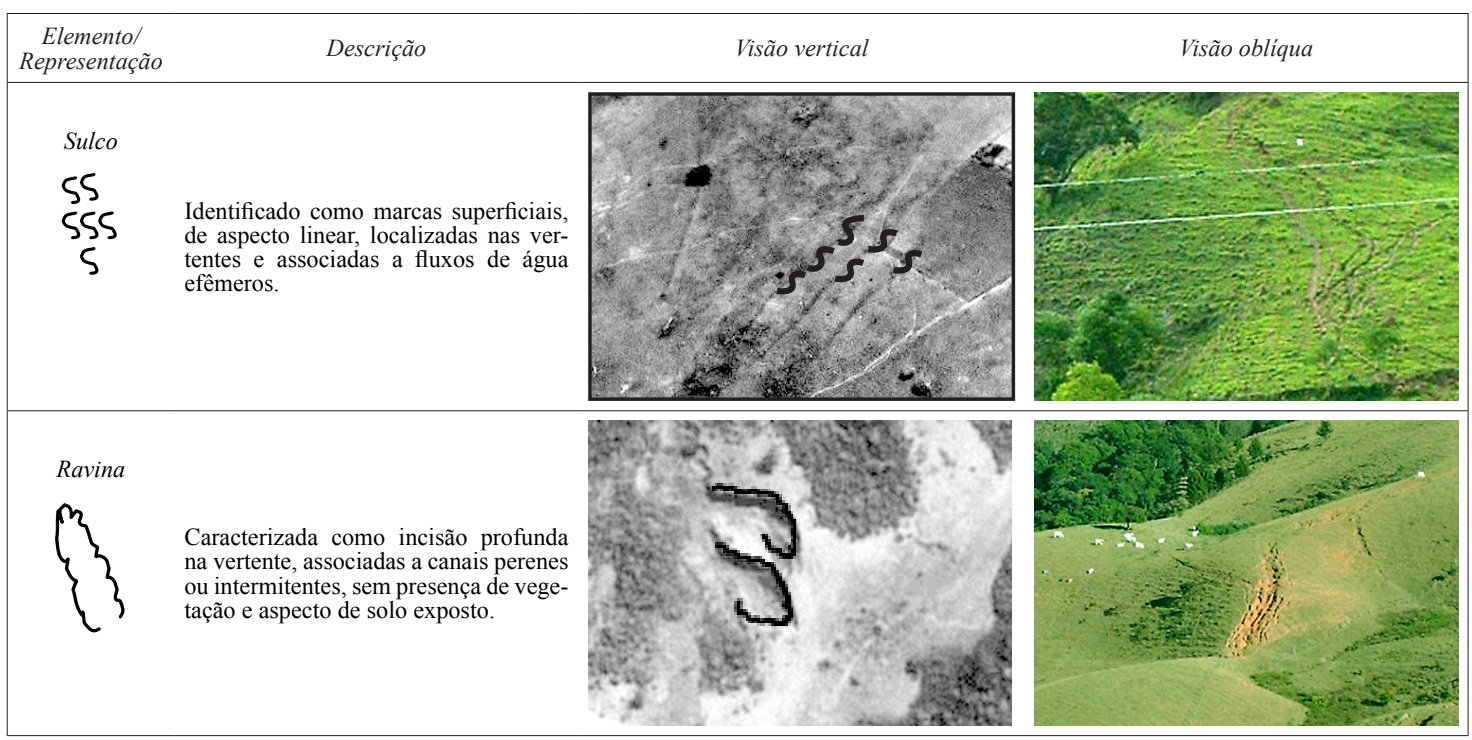

zada foi a do sistema de mapeamento morfológico proposto por SAVIGEAR (1965), adaptado por COOKE \& DOORNKAMP (1990). Os pressupostos dessa legenda são de caráter puramente morfológico, pois buscam a representação fiel da complexidade das formas e suas micro-feições, a partir do mapeamento das mudanças (change of slope) e as rupturas de declividades (break of slope) observadas ao longo das vertentes. Para sistematizar a legenda utilizada nesta carta morfológica elaborou-se um quadro (Quadro 2) com as seguintes informações: morfologia mapeada, descrição conceitual, visão vertical (foto-aérea), visão oblíqua (fotos do campo), representação utilizada no mapeamento, e um desenho esquemático da vertente ilustrando a posição das rupturas e mudanças de declividade.

Durante a pesquisa o controle de campo foi fundamental, tanto para reconhecimento geomorfológico/geológico da bacia e controle da fotointepretação, quanto para levantamento morfológico dos materiais em três formas de relevo: superfície rugosa, cicatriz com patamar e depressão. Essas formas foram escolhidas em função da magnitude e frequência em que foram mapeadas em vários setores da bacia. Neste levantamento de campo foram analisados 7 exemplos dessas formas, sendo 3 superfícies rugosas, 3 cicatrizes com patamar e 1 depressão, que corresponderam a um total de 12 sondagens e 5 descrições de perfis de solo localizados em cortes de estradas, apresentados na forma de pranchas com fotos de campo, ilustrando as feições, além de uma síntese das descrições morfológicas.

\section{RESULTADOS E DISCUSSÕES}

\subsection{Formas de relevo}

A elaboração da carta morfológica (Anexo 1) possibilitou a identificação de uma diversidade de formas ao longo de toda a bacia do ribeirão do Baú. Com o intuito de facilitar a análise e descrição 
QUADRO 2 - Sistematização da legenda do mapeamento morfológico na escala 1:10.000.

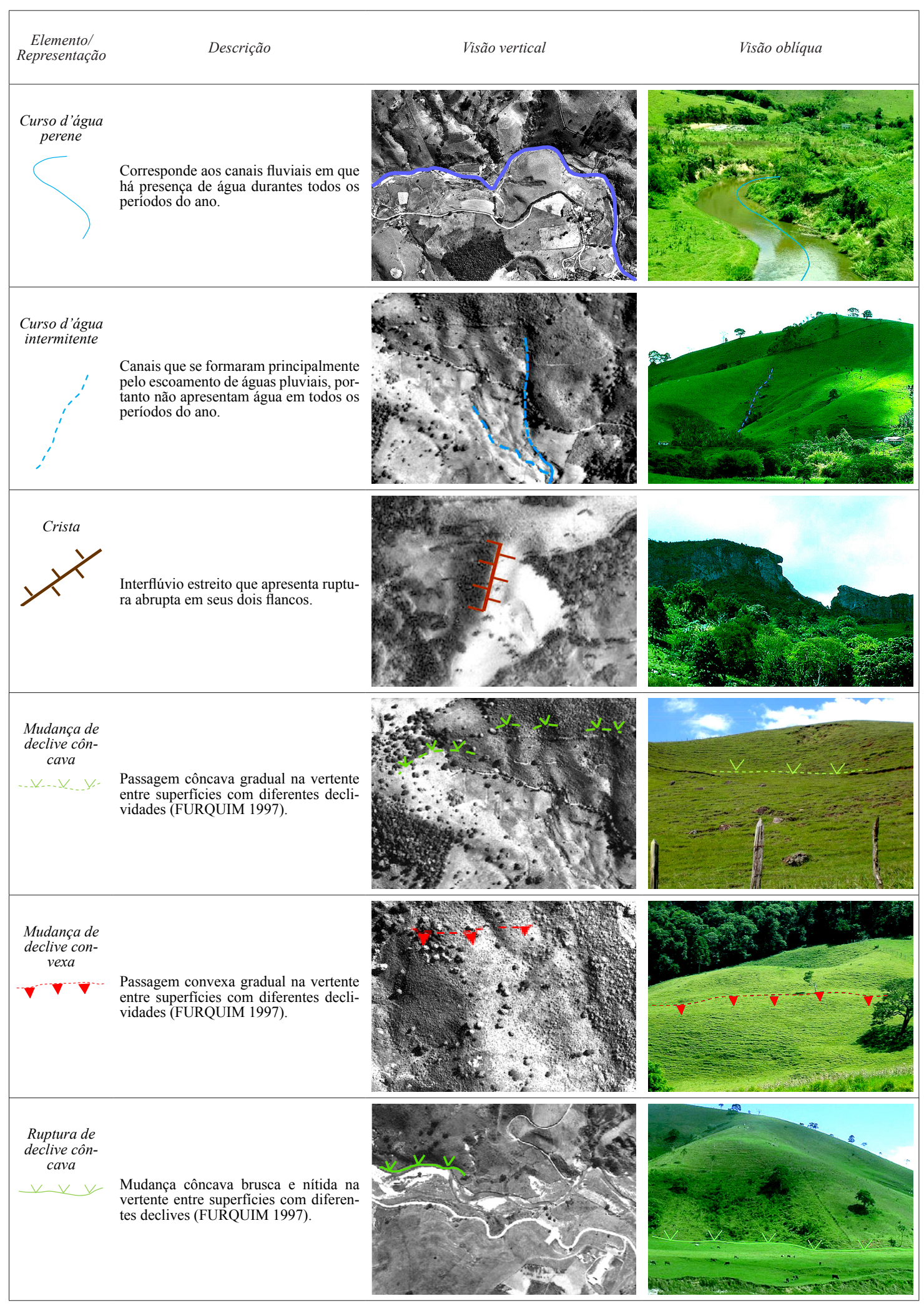


QUADRO 2 - (cont.) Sistematização da legenda do mapeamento morfológico na escala 1:10.000.

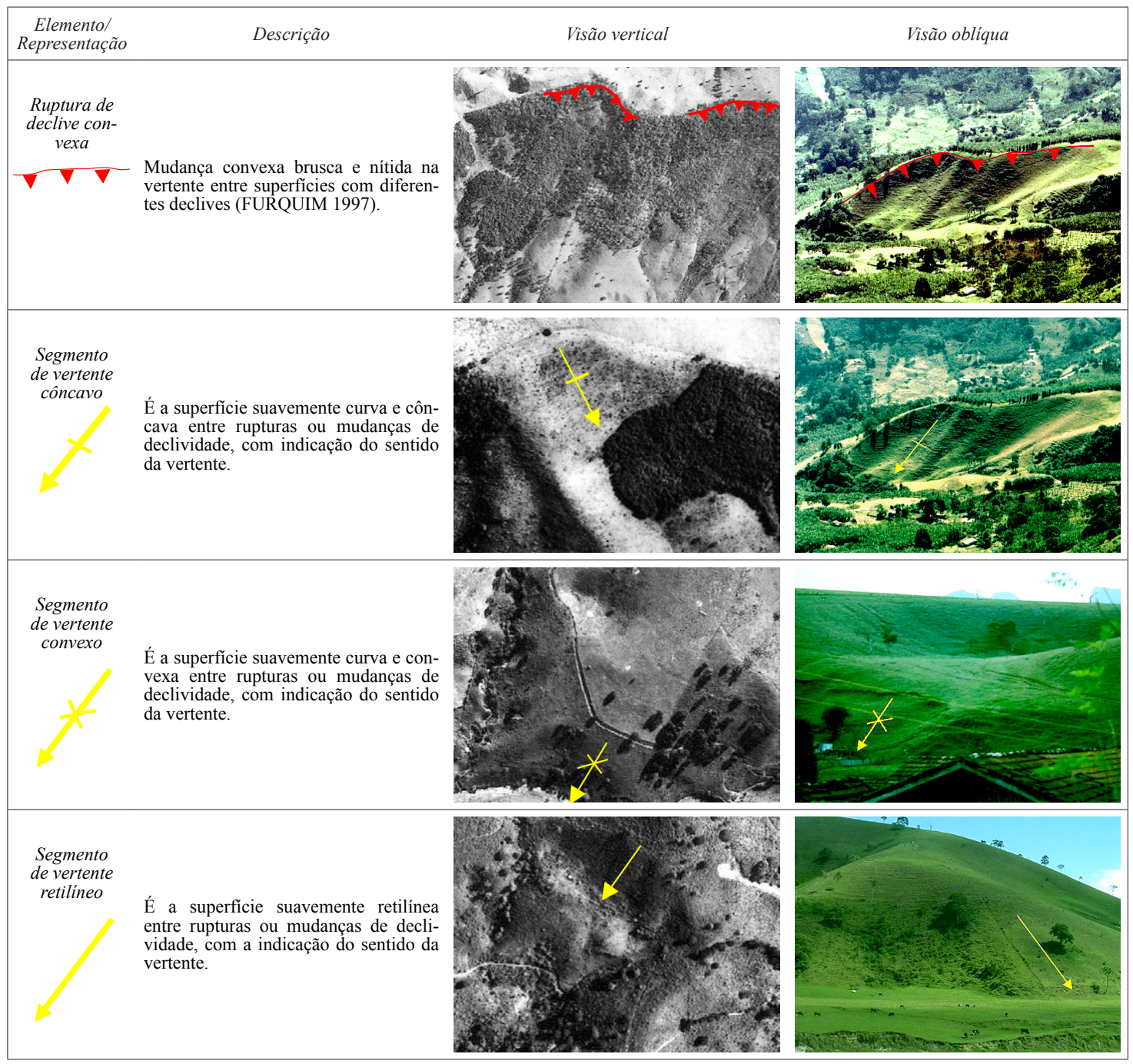

deste produto cartográfico, optou-se em abordar a descrição das formas pelos setores funcionais do relevo: interflúvios, vertentes e vales.

\subsubsection{Interflúvios}

Os interflúvios que delimitam a bacia apresentam formas diferenciadas. O interflúvio da margem direita, que separa as bacias do ribeirão do Baú e do Paiol Grande, orientado na direção NE-SW, apresenta forma escarpada com rupturas abruptas e cristas rochosas alinhadas (complexo do Baú-Bauzinho-Ana Chata). É topograficamente descontínuo, apresentando rebaixamentos formando colos com diferentes amplitudes de abertura. As cristas rochosas do conjunto do Baú apresentam desenho sinuoso, às vezes com duplo pa- redão, paralelos entre si, porém deslocados em relação ao eixo NE-SW.

A sua altitude tende a diminuir no sentido jusante da bacia, sendo que a partir aproximadamente de $1300 \mathrm{~m}$ a configuração muda significativamente, apresentando uma forma convexa recortada por colos, definindo assim uma paisagem de topos isolados. O limite sudeste-sudoeste da bacia apresenta um desenho com geometria bastante sinuosa. Este interflúvio possui formas predominantemente convexas e com forte presença de topos isolados delimitados por colos, com diminuição significativa da altitude no sentido jusante.

A articulação entre os dois divisores que margeiam a bacia se dá por um colo muito amplo e rebaixado, onde se encontram as nascentes do 
ribeirão do Baú. Este divisor separa a bacia do ribeirão do Baú da bacia do ribeirão dos Marmelos, posicionado na sua retaguarda, estando o vale dos Marmelos assentado em um compartimento topográfico mais elevado (Planalto de Campos do Jordão).

A forma de colo, em posição muito rebaixada, associada à presença de um cotovelo no ribeirão dos Marmelos, traz indícios de uma possível situação de captura. Quanto aos interflúvios secundários, destacam-se os que separam as drenagens do córrego da Pedra do Baú de outros tributários do ribeirão do Baú, e o divisor entre o ribeirão dos Barradas e o córrego do Campo.

O eixo sudeste do interflúvio do córrego da Pedra do Baú, paralelo ao divisor principal (Pedra do Baú), também está orientado na direção NESW. Apresenta, no entanto, um desdobramento no seu eixo transversal com mudança no sentido $\mathrm{N}-\mathrm{S}$, onde estão alojadas as cabeceiras do córrego da Pedra.

O interflúvio entre córrego do Campo e o ribeirão do Barradas é bastante assimétrico, pois apresenta feições escarpadas com rupturas bem marcadas para o lado Barradas e formas predominantemente convexas no lado oposto. Este divisor está orientado também na direção NE-SW, coincidindo com a orientação dos interflúvios principais da bacia do Baú.

A forma dos interflúvios em crista é pouco expressiva ao longo de toda a bacia do ribeirão do Baú, sendo que a maior concentração ocorre nas proximidades do ribeirão dos Barradas e no conjunto da Pedra do Baú. Na bacia do Barradas apresentam-se paralelas entre si e alinhadas na direção NE-SW, acompanhando, portanto, a orientação geral do vale do ribeirão do Baú e das principais formas estruturais (facetas, escarpas e patamares). No entanto, interflúvios estreitos com vertentes com rocha aflorante ou em subsuperfície são mais comuns.

Os espigões secundários apresentam predominância de formas convexas, com presença de topos isolados, principalmente próximo ao córrego do Torto e do ribeirão dos Barradas.

\subsubsection{Vertentes}

As vertentes que modelam os interflúvios no vale do ribeirão do Baú possuem dominantemente formas côncavas e convexas e secundariamente retilíneas. No mosaico de feições criado pelo padrão de dissecação destacam-se como ma- crofeições: as concavidades amplas, as cicatrizes de escorregamentos, os patamares e as facetas.

Neste mapeamento, as formas denominadas de concavidades amplas apresentam contornos arredondados com rebordos nítidos, geometrias diversas, indo do desenho contínuo ao mais festonado, podendo ser alongadas e estreitas ou amplas e quase circulares.

Essas formas estão presentes principalmente nos setores mais declivosos e topograficamente mais elevados das vertentes, com clara articulação e interação a eixos do vale. No interior delas instalam-se as drenagens, tanto perenes como intermitentes, sendo que em alguns casos os fluxos intermitentes se apresentam de forma caótica.

Associadas a essas concavidades foram delimitadas as feições denominadas de "superfícies rugosas", que se localizam nos setores topograficamente inferiores das vertentes. Receberam esta denominação descritiva por apresentar nas fotos-aéreas textura rugosa muito característica; no campo, constatou-se que essas irregularidades da superfície estão associadas à presença de blocos e matacões de rocha. Outra importante observação a respeito desta forma é a ocorrência de um intenso processo de reincisão pelos fluxos de água, alguns perenes e muitos intermitentes, que remodelam a feição original criando microformas subordinadas ao complexo arranjo desse conjunto. Sendo assim, a ocorrência dessas duas formas, concavidades amplas e "superfícies rugosas", e a estreita correlação espacial e funcional que elas possuem, indicam certamente uma sequência de eventos erosivos pretéritos de grande magnitude e sincrônicos.

Além dessas formas maiores, outras pequenas concavidades aparecem distribuídas por diversos setores das vertentes. Em função das suas características foram classificadas como cicatrizes de escorregamentos. Essas cicatrizes de escorregamentos podem aparecer associadas a cursos d'água (perenes ou intermitentes), em barrancas de rios perenes e no interior das concavidades amplas. Podem ser profundas ou superficiais e apresentam dimensões variadas.

Destacam-se nesse grupo de formas, cicatrizes correspondentes a concavidades com paredes verticais, tendo na base uma ruptura côncava abrupta no contato com um patamar. Aparecem com maior frequência nas vertentes da margem direita do vale. Em alguns casos, o patamar do interior das concavidades, pelo seu aspecto plano e destacado, sugere a presença de laje rochosa. 
Com pequena representatividade em termos quantitativos, estão as depressões fechadas. Essas formas receberam tal denominação por serem concavidades praticamente circulares, sem conectividade aparente com o sistema fluvial. As depressões fechadas não aparecem associadas diretamente a outras formas e não apresentam um padrão topográfico em suas ocorrências, ou seja, não apresentam elementos morfológicos ou topográficos determinantes.

Geralmente interpretadas como derivadas da ação antrópica, as feições erosivas lineares, como ravinas e sulcos, são comuns na área estudada. Estas são encontradas em altitudes variadas, mas estão sempre associadas a cursos d'água perenes ou intermitentes, podendo aparecer isoladas ou em conjunto.

Além das formas mencionadas, destacam-se, nas vertentes do trecho montante da bacia dois conjuntos de formas, as facetas e os patamares, feições estas classicamente associadas ao controle tectônico das formas. As facetas (triangulares e trapezoidais) localizam-se na parte alta das vertentes da margem esquerda do ribeirão do Baú. Apresentam feição retilínea no sentido da declividade e seu desenho é destacado pelos cursos d'água que as circundam. No lado oposto do vale, em posição de baixa vertente, na passagem para o eixo fluvial, localiza-se uma sequência de patamares escalonados com dimensões variadas. Mostram uma ruptura côncava contínua no contato com as vertentes e uma convexidade acentuada para jusante. Essas formas aparecem uma ao lado da outra com um leve desnível topográfico, formando degraus amplos e assimétricos ao longo da margem direita do ribeirão do Baú.

\subsubsection{Vales}

Os vales da bacia do ribeirão do Baú podem ser divididos em três tipos: vales encaixados em forma de "v", vales encaixados com presença de soleiras, e vales de fundo "chato" (planície aluvial).

Os vales encaixados em forma de " $\mathrm{v}$ " correspondem ao padrão de entalhe da bacia e estão associados a cursos d'água perenes, em situações de média e alta declividade. Em alguns casos, onde ocorrem rupturas abruptas no seu perfil longitudinal, podem ser encontradas cachoeiras. Destacase esse tipo de vale no setor montante do ribeirão do Baú, no córrego da Pedra e no ribeirão dos Barradas.
Os vales encaixados com presença de soleiras aparecem delimitados por vertentes com declividades acentuadas formando pequenos canyons. Em algumas situações, essas soleiras são responsáveis por gerar planícies aluviais suspensas e, em outros casos, afunila e interrompe a planície. Em virtude disso, a planície aluvial do ribeirão do Baú, que se inicia próxima à confluência do afluente córrego da Pedra, não se apresenta de forma contínua ao longo de toda a sua extensão.

Os terraços observados no vale do Baú estão relacionados a diferentes momentos da evolução fluvial. Apresentam formas fragmentadas indicando reincisão fluvial. Dominam blocos e seixos sugerindo regime torrencial do sistema. Estão bem distribuídos ao longo da planície e aparecem em pelo menos dois níveis acima do plano do talvegue.

\subsection{Compartimentação morfológica (Anexo 2)}

A partir das correlações entre os dados de hipsometria, declividade (Anexo 2) e da morfologia (Anexo 1) da bacia do ribeirão do Baú, pôde-se individualizar nesta escala de análise sete compartimentos morfologicamente distintos (Anexo 2), descritos a seguir.

4.2.1 Compartimento A - Superfície de Campos do Jordão

Este compartimento foi individualizado por apresentar uma morfologia diferenciada e um grau de dissecação menor em relação aos demais compartimentos da bacia. Neste trecho encontram-se as maiores altitudes, predominando valores superiores a $1600 \mathrm{~m}$. As vertentes apresentam declividades inferiores a $30 \%$, sendo que em alguns setores não superam $5 \%$.

Predominam neste compartimento interflúvios com rupturas convexas e topos arredondados bem distribuídos. Esta morfologia é a descrita por MODENESI (1988) no modelado dos altos campos do Planalto de Campos do Jordão (Figura 3). Este compartimento mostra também o mosaico de lombas com campos e vales com matas, típico do Planalto de Campos do Jordão.

\subsubsection{Compartimento A' - Campos do Serrano}

O compartimento Campos do Serrano apresenta feições morfológicas muito semelhantes ao da superfície de Campos do Jordão, diferenciando-se principalmente, por apresentar altitudes 


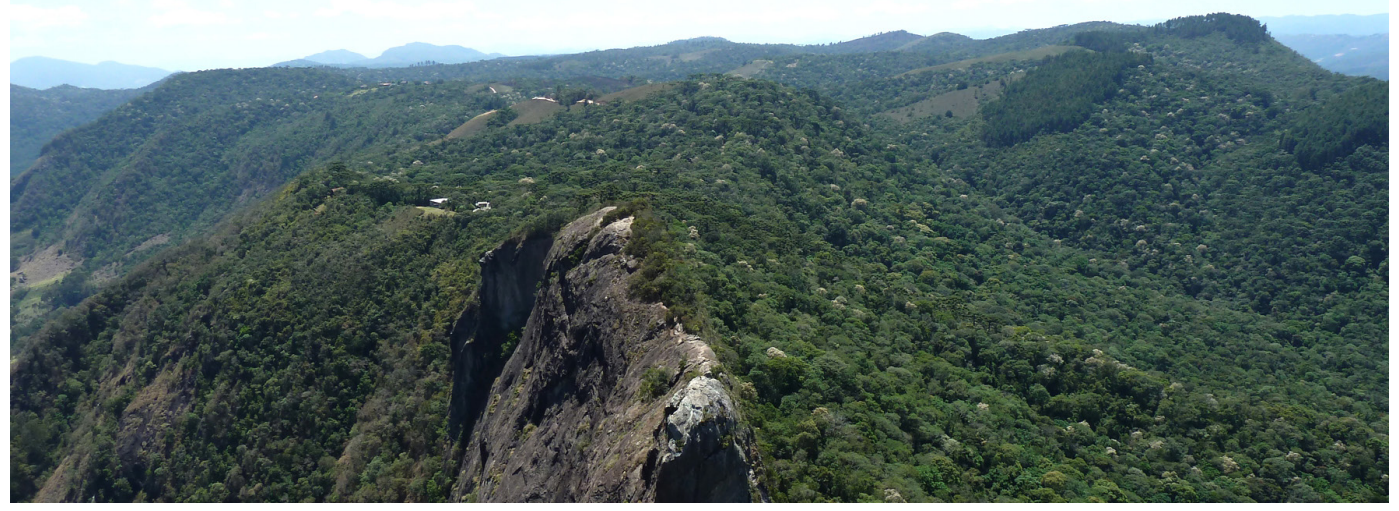

FIGURA 3 - Em primeiro plano, parte do complexo rochoso do Baú-Bauzinho-Ana Chata (Bauzinho); no segundo plano observa-se o modelado dos altos campos do Planalto de Campos do Jordão (compartimento A e A') (Foto cedida por Silvio T. Hiruma).

pouco inferiores $(1700 \mathrm{~m})$ e amplitudes altimétricas menores.

\subsubsection{Compartimento B - Alto curso:} Cabeceiras do Baú

Este compartimento apresenta-se como a importante frente remontante de dissecação do Planalto de Campos do Jordão (Figura 4), onde predominam vertentes com declividades mais acentuadas entre 12 e $30 \%$. As altitudes variam de $1000 \mathrm{~m}$ no fundo do vale a $1800 \mathrm{~m}$ nos trechos mais elevados, que correspondem aos interflúvios que delimitam a bacia do ribeirão do Baú com o planalto.

Observa-se uma variedade de formas ligadas a processos de vertentes e uma assimetria
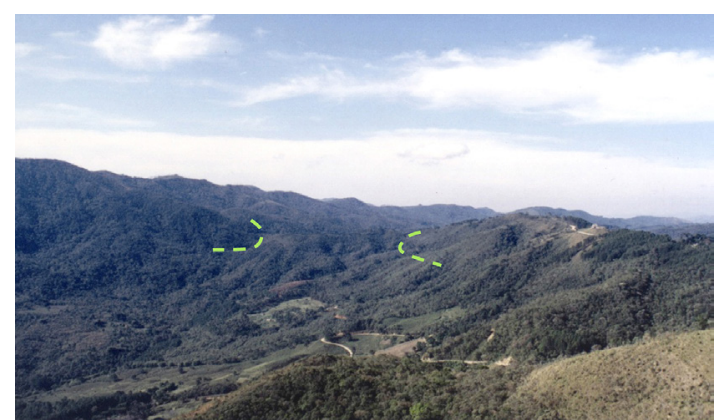

FIGURA 4 - O compartimento B apresenta o rebaixamento topográfico (colo) da cabeceira do ribeirão do Baú em relação ao seu entorno. Este setor da bacia apresenta-se como importante frente de dissecação do Planalto de Campos do Jordão (foto: R. Aranha). entre as vertentes da margem esquerda e direita. As vertentes do setor nordeste apresentam rupturas abruptas bem marcadas por cornijas e divisores escarpados, com declividades que chegam até $47 \%$. No entanto, a declividade tende a diminuir na média e baixa vertente em função da presença de amplos patamares. Já as vertentes opostas são mais curtas e com declividades superiores a $30 \%$, principalmente nas proximidades das feições em facetas trapezoidais e triangulares (Figura 5).

Vertentes com facetas e patamares são os diferenciais morfológicos deste compartimento, pois tais formas não foram mapeadas em outros setores da bacia. Tais formas podem ser um indicativo de processos neotectônicos, como observou HIRUMA et al. (2001) no Planalto de Campos do Jordão.

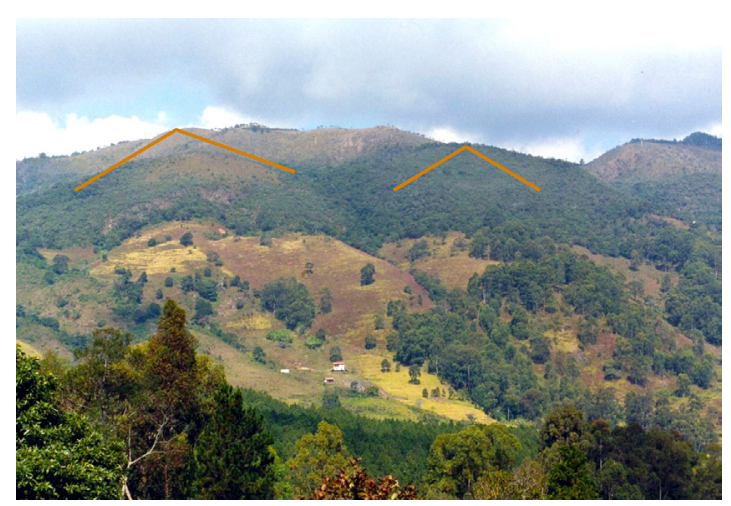

FIGURA 5 - As facetas (triangulares e trapezoidais) são formas do relevo singulares do compartimento B (foto: R. Aranha). 
4.2.4 Compartimento C - Médio curso do flanco sul: Interflúvios dissecados das bacias do Barradas e do córrego do Campo

Este compartimento apresenta algumas semelhanças em relação ao compartimento $\mathrm{B}$, uma vez que representa também uma porção dissecada do Planalto de Campos do Jordão. Sua altitude varia de $1000 \mathrm{~m}$ a $1200 \mathrm{~m}$, no trecho jusante da bacia do ribeirão dos Barradas e córrego do Campo, atingindo $1600 \mathrm{~m}$ no contato e transição com o compartimento da superfície de Campos do Jordão.

O ribeirão dos Barradas apresenta forte condicionamento estrutural, encaixado sobre um lineamento (falha), e caracteriza-se por vertentes escarpadas, vale profundos e em " $v$ ". Possui cristas e paredões na margem direita e poucos entalhes, enquanto a margem esquerda é recortada por drenagens paralelas com trechos angulosos e cabeceiras em arco, conferindo uma característica altamente assimétrica.

Esse compartimento foi individualizado também por apresentar uma forte concentração de formas representadas como concavidades amplas (Figura 6), em vertentes com declividades superiores a $30 \%$. No interior dessas formas aparecem alojados planos ou patamares com microformas arredondadas, de perfis convexos, caoticamente distribuídos, e que vistos nas fotos aéreas, apresentam-se como superfícies com alta rugosidade, principalmente em trechos das vertentes em altitudes superiores a $1300 \mathrm{~m}$.

Em alguns casos encontram-se no interior das concavidade formas erosivas (sulcos) relacionados ao fluxo de água intermitente. Apresentam-

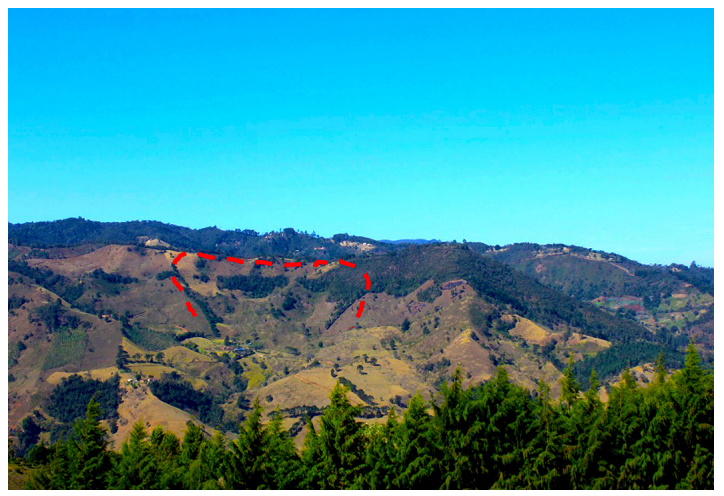

FIGURA 6 - Compartimento C, predomínio de vertentes com feições denominadas de concavidades amplas (foto: R. Aranha). se anastomosados, colocando em destaque as irregularidades dos materiais heterométricos - presença de blocos com distribuição caótica - no meio de material alterado. Podem ocorrer matacões e afloramentos rochosos (Figura 7).

\subsubsection{Compartimento D - Médio curso do} flanco norte: Vertentes íngremes do córrego da Pedra do Baú e do Baú do Centro

Este compartimento foi individualizado devido à variedade de formas relacionadas a movimentos de massa, embora as características morfométricas (altitudes entre $1000 \mathrm{~m}$ a $1600 \mathrm{~m}$ e declividades $>12 \%$ ) não constituam um diferencial relevante em relação aos outros compartimentos.

As formas de relevo que se destacam neste compartimento são: concavidades amplas, superfícies rugosas, cicatrizes de escorregamentos, cicatrizes com patamar e depressão fechada. As concavidades amplas e as superfícies rugosas apresentam formas geométricas diferenciadas, variando no desenho e no tamanho.

As cicatrizes de escorregamentos aparecem distribuídas em várias posições das vertentes, sendo que em alguns casos localizam-se no interior das concavidades amplas, muitas vezes associadas à drenagem intermitente. As cicatrizes com patamar, embora não se manifestem em grande quantidade, são importantes para a compreensão da morfologia geral da bacia, uma vez que o patamar delimitado no interior da concavidade pode ser interpretado como um condicionante estrutural ou litológico.

Dentre todas as formas mapeadas nesta bacia a depressão fechada (Figura 8) é uma das mais singulares; são concavidade praticamente circulares

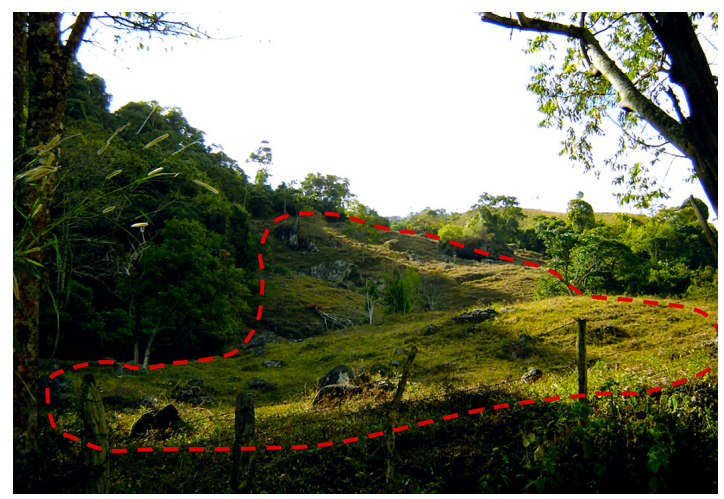

FIGURA 7 - No interior das concavidades amplas encontra-se uma superficie irregular, com presença de blocos, aqui denominada de superficie rugosa (foto: R. Aranha). 
que não possuem comunicação com cursos d'água perenes ou intermitentes e não aparecem associadas a outras formas.

4.2.6 Compartimento E - Complexo Baú Bauzinho - Ana Chata: Divisor com afloramento de rocha e frente escarpada descontínua

Este é o menor compartimento morfológico da bacia do ribeirão do Baú e foi delimitado pela singularidade apresentada, tanto em relação à forma quanto à estrutura. Apresenta declividades superiores a $30 \%$ e altitudes maiores que $1600 \mathrm{~m}$. Neste trecho da bacia localiza-se a feição do relevo mais conhecida desta região, a Pedra do Baú, com aproximadamente $1900 \mathrm{~m}$ de altitude.

O compartimento é composto pelas formas escarpadas e em crista alinhadas na direção NESW (Figura 9). Essas formas são descontínuas, interrompidas por uma série de colos, e desdobradas no setor mais jusante. Este setor representa o divisor mais imponente de toda a bacia do ribeirão do

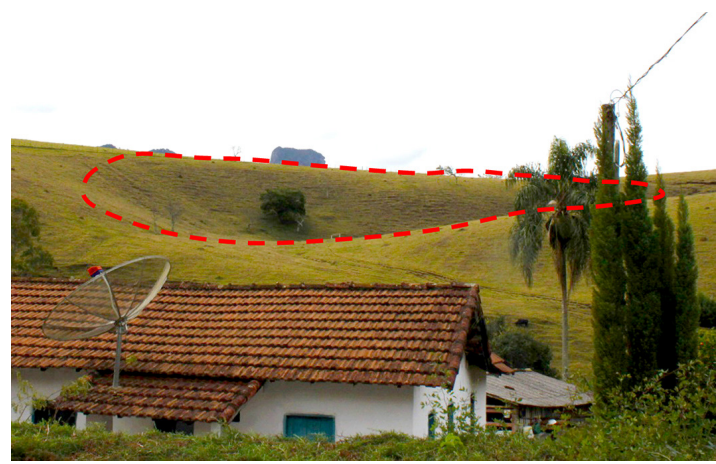

FIGURA 8 - Compartimento (D): formas de relevo denominadas de depressão fechada (foto: R. Aranha).

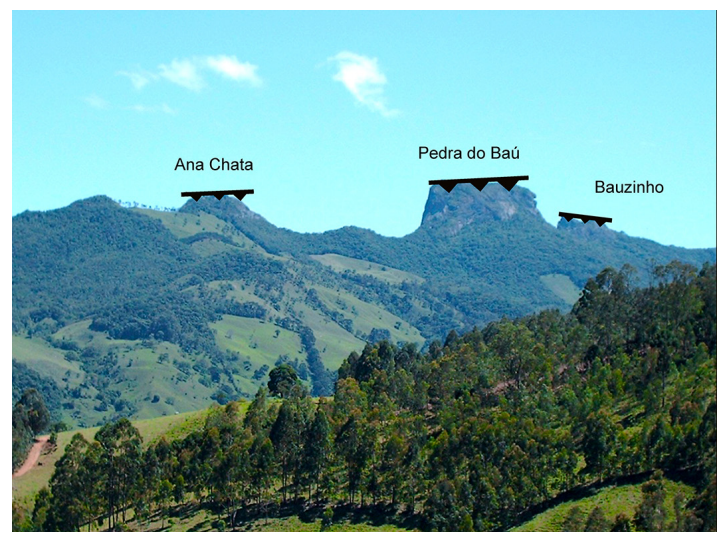

FIGURA 9 - O compartimento E é caracterizado pela presença de interflúvio com afloramento rochoso e frentes escarpadas descontínuas, denominadas de Bauzinho, Pedra do Baú e Ana Chata (foto: R. Aranha).
Baú, onde se destaca o conjunto de rochas aflorantes da Pedra do Baú, Ana Chata e Bauzinho.

\subsubsection{Compartimento F - Planície do ribei-} rão do Baú

A planície do ribeirão do Baú é delimitada pelas rupturas côncavas que marcam o contato entre as vertentes direita e esquerda do ribeirão do Baú com o plano aluvial das várzeas. Tem a montante, forma estreita, onde o canal e vale principal apresentam depósitos de blocos em posições de cone/ terraço e na calha do rio, denunciando momentos torrenciais no sistema. Ao longo do seu eixo, este compartimento apresenta uma declividade inferior a $5 \%$. As altitudes variam bastante; o trecho montante atinge $1200 \mathrm{~m}$ e o jusante chega a altitudes menores que $900 \mathrm{~m}$.

As principais formas deste compartimento são os terraços, a planície aluvial e as soleiras.

A planície aluvial aparece segmentada ao longo de todo o compartimento, sendo que em alguns setores ela se apresenta mais larga e em outros um estreitamento (Figura 10).

A descontinuidade da planície pode estar relacionada à presença de soleiras que criam barramentos naturais, com diferentes níveis de base. Comparando-se a carta morfológica e a clinográfica (Anexos 1 e 2), observa-se uma coincidência entre os trechos em que a planície aluvial é interrompida e o aumento da declividade, mostrando a existência de rupturas significativas ao longo do ribeirão do Baú.

Além disso, as anomalias na drenagem, como por exemplo, os cotovelos, podem influenciar no processo de sedimentação do rio e, consequentemente, na formação da planície aluvial.

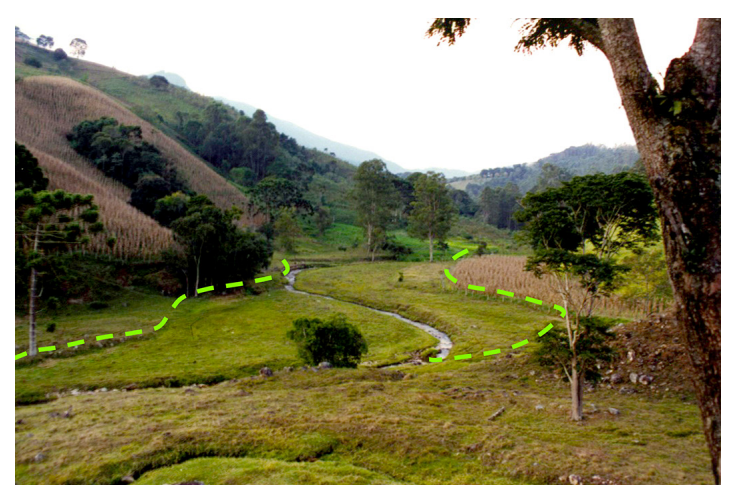

FIGURA 10 - A planície aluvial do ribeirão do Baú (compartimento F) apresenta-se de forma descontínua ao longo da bacia (foto: R. Aranha). 
Os terraços, bem distribuídos ao longo do vale, estão sendo retrabalhados e reentalhados pela ação fluvial mais recente (Figura 11).

4.2.8 Compartimento G - Baixo curso: Morros e colinas de topos convexos

Este compartimento apresenta altitudes inferiores a $1200 \mathrm{~m}$, predominância de formas convexas e vertentes com declividades inferiores a $30 \%$.

Observa-se neste setor da bacia, interflúvios com formas bastante arredondadas e uma sucessão de topos e colos. É uma zona de colinas e morros com topos individualizados pelos recortes da drenagem. Os interflúvios principais conectam-se com os secundários, muitas vezes, por meio de um segmento de vertente retilínea e inclinada, com concavidades laterais correspondentes a pequenos anfiteatros de cabeceira de drenagens efêmeras (Figura 12).

Neste compartimento as cicatrizes de escorregamentos aparecem em menor quantidade e, na maioria dos casos, associadas a cursos d'água perenes e intermitentes localizadas principalmente nos setores baixos das vertentes.

4.3 Carta morfológica de detalhe - Baú do Centro $(1: 10.000)$ (Anexo 3)

A área escolhida para o estudo de detalhe localiza-se no médio curso do ribeirão do Baú, em um setor da sua margem direita, entre a planície aluvial e as cristas meridionais do Complexo Baú-Bauzinho-Ana Chata.

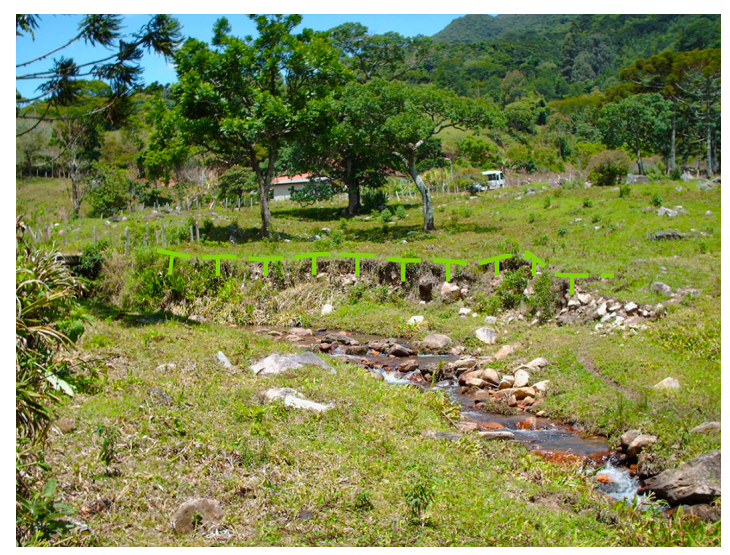

FIGURA 11 - Setor jusante do compartimento F. Observa-se terraço de várzea, com materiais heterométricos e caóticos, sendo, em alguns casos, retrabalhados pela ação fluvial (foto: R. Aranha).
A leitura da carta morfológica (Anexo 3) correlacionada com a carta clinográfica (Anexo 3) permitiu destacar que predominam na área interflúvios topograficamente desdobrados, onde dominam formas convexas e declividades superiores a $20 \%$. Os setores mais declivosos (acima de $40 \%$ ) marcam as vertentes laterais dos interflúvios (principal e secundários); estes mostram topos individualizados e com baixas declividades (inferiores a 7\%), sendo os limites dos topos, marcados por mudanças ou rupturas convexas.

O ribeirão do Baú, ao longo de quase toda a sua extensão, apresenta orientação NE-SW, concordante com alinhamento de falha indiscriminada. Mostra padrão meandrante num plano aluvial de largura variável, com estrangulamentos e mudanças abruptas de direção, formando localmente baionetas de direção ortogonal ao alinhamento geral. Esses cotovelos revelam forte condicionamento estrutural.

As drenagens perenes, localizadas nas vertentes da margem direita, apresentam-se paralelas entre si, com orientação NE-SW.

O plano aluvial, contendo a planície, terraços e setores da baixa encosta, encontra-se muito bem delimitado, marcado por rupturas côncavas, e declividades que variam entre $5 \%$ a $13 \%$.

Os interflúvios principais (margem direita), que fazem parte da Serra do Baú, delimitam a bacia a norte e noroeste, e a separam da bacia do Monjolinho. São estreitos, alongados, descontínuos, de direção geral NE-SW, mas com desdobramento para SW. Apresentam-se individualizados por rupturas convexas e circundados por

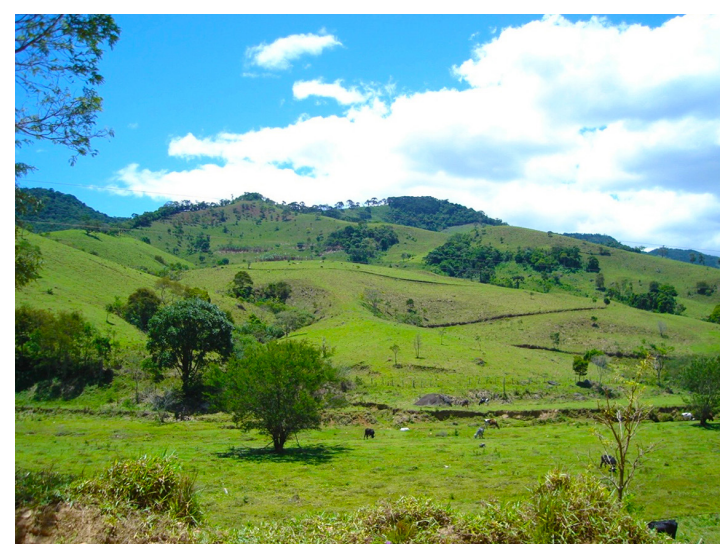

FIGURA 12 - Compartimento G: predomina nesta paisagem as colinas de topos convexos com declividades inferiores a $30 \%$, ocorrendo em altitudes inferiores a $1200 \mathrm{~m}$ (foto: R. Aranha). 
vertentes de altas declividades (acima de 30\%). Os topos estreitos mostram declividades baixas, entre $7 \%$ e $13 \%$.

No terço superior das vertentes da margem direita do Baú, além da alta declividade (acima de 30\%), observam-se segmentos predominantemente côncavos e retilíneos, que vão se transformando em convexos, conforme ocorre a diminuição da altitude e o aumento da dissecação. O terço médio das vertentes apresenta-se bastante dissecado por drenagens perenes e intermitentes. Algumas sub-bacias mostram uma gradual diminuição da declividade, formando patamares com inclinações que variam de $7 \%$ a $20 \%$, e formas predominantemente convexas. Nesses setores observam-se microfeições que dão aspecto irregular a superfície, rugosidade, causada por uma infinidade de reentrâncias e saliências, mapeadas na carta morfológica como rupturas e mudanças convexas de declividade.

No setor sul, margem esquerda do Baú, onde o recorte do detalhe cartográfico aqui apresentado abrangeu apenas o terço inferior das vertentes, ocorrem pequenas planícies suspensas, identificadas claramente na carta clinográfica como trechos descontínuos, de baixa declividade, associados à drenagem e delimitadas, na maioria dos casos, por rupturas côncavas. Essas planícies suspensas estão na retaguarda de pequenas soleiras e/ou cachoeiras presentes nesses cursos d'água. As vertentes desse setor sul apresentam feições retilíneas e convexas mais contínuas, com menos ocorrência de rupturas de declividade, caracterizando, em alguns setores, formas de rampas e patamares.

No terço inferior das vertentes, tanto da margem direita quanto esquerda do ribeirão do Baú, observa-se que a dissecação individualizou morros de topos convexos e pequenos interflúvios alongados. Na margem esquerda, alguns setores das vertentes apresentam rampas de geometria retilínea e com menores declividades que as vertentes opostas. Ao longo de toda a área mapeada, mas predominantemente, no terço médio e inferior das vertentes, ocorrem formas isoladas, de contornos arredondados, delimitadas por rupturas convexas e paredes íngremes, e que apresentam em seu interior pequenos patamares planos ( $7 \%$ a $13 \%$ de declividade) demarcados por rupturas côncavas. Essas feições correspondem a cicatrizes com patamar e pequenas depressões.

\subsection{Relações entre formas e materiais}

O mapeamento morfológico da bacia do Baú (1:50.000) possibilitou, além da caracterização e análise da distribuição espacial das formas de relevo, a observação de feições recorrentes ao longo de toda a sua extensão. Dentre elas destacam-se três formas: as superfícies rugosas, as cicatrizes com patamar e as depressões.

As superfícies rugosas localizam-se no interior de cabeceiras de drenagem, caracterizadas por um lóbulo ondulado com grande presença de blocos em superfície e escoamento superficial difuso. Esta forma assemelha-se à feição deposicional de complexo de rampas descrita por MEIS \& MONTEIRO (1979).

As depressões e as cicatrizes com patamar ocorrem nas ombreiras de interflúvios secundários e apresentam formas côncavas de geometria circular ou semicircular, fechadas ou ligadas a drenagens efêmeras.

Realizou-se um controle de campo mais detalhado em áreas mapeadas como superfícies rugosas (I, II, III), cicatrizes com patamar (I, II) e uma depressão, onde foram observadas características morfológicas da superfície e dos materiais, a partir de tradagens e perfis em cortes de estrada (Figura 13).

\subsubsection{Superfícies rugosas}

As superfícies rugosas analisadas localizam-se nos setores da média vertente, com declividades que variam entre 20 e $40 \%$, apresentando diversos níveis de patamar associados e grande presença de blocos em superfície.

Essas formas tiveram seus materiais analisados através de tradagens (T6 a T10) e em perfis localizados em cortes de estradas (P1 e P3 a P6). As superfícies rugosas denominadas de I e II (Figura 14) encontram-se associadas à mesma concavidade ampla, mas em posições altimétricas diferentes.

A tradagem feita na superficie rugosa I (T6) mostrou material predominantemente de textura argilo-areno-siltosa, de cor bruno-avermelhado, com presença de fragmentos de rocha desde a camada superficial (Figura 14).

Alguns metros acima na vertente (tradagem T7, Figura 14), ocorrem blocos já em superfície e profundidade máxima de $40 \mathrm{~cm}$.

$\mathrm{Na}$ superficie rugosa II foram realizadas três sondagens (T8, T9 e T10) e analisado um perfil de solo (P1), localizado em um barranco de estrada que corta esta feição (figura 14). A escolha 

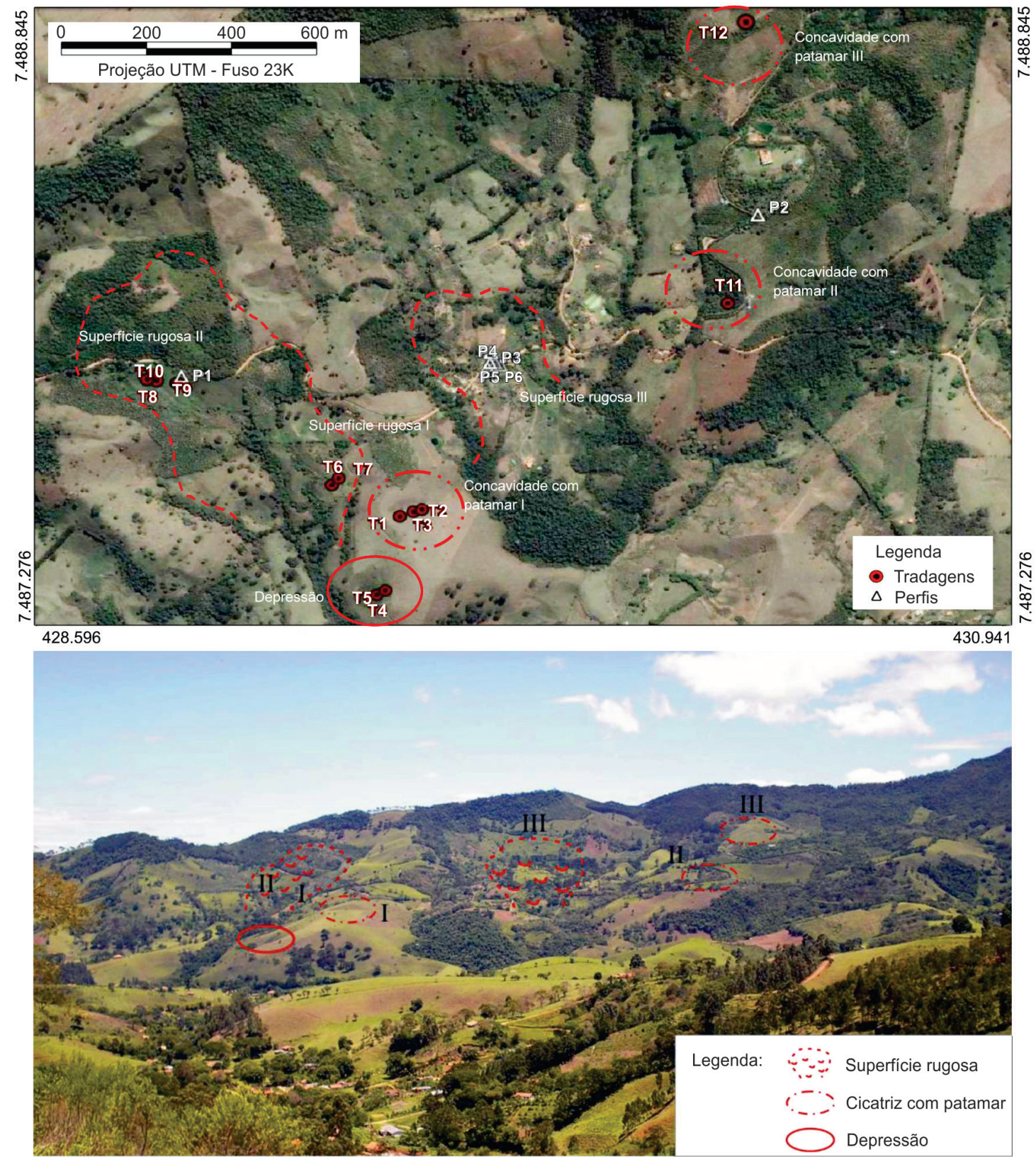

FIGURA 13 - Localização das descrições morfológicas dos perfis e tradagens.

dos pontos para tradagens privilegiou os setores de maior e menor declividade, bem como os patamares encontrados em seu interior.

Observou-se nas tradagens um material bruno/bruno-avermelhado pouco desenvolvido, com textura variando de argilo-areno-siltosa a argilo-siltosa, com presença de fragmentos de rocha a partir de $40 \mathrm{~cm}$ de profundidade, indicando material de alteração. Apenas a tradagem 9 (Figura 14), localizada no eixo de uma drenagem intermitente, apresentou um material mais acinzentado (bruno- -acinzentado escuro), areno-argilosa, mais úmido $(40-70 \mathrm{~cm})$ e com um pouco de água livre entre 70 e $80 \mathrm{~cm}$.

No perfil 1 (P1 - Figura 14) nota-se grande presença de cascalhos e blocos, apresentados de forma caótica, sendo que os menores encontram-se bastante alterados. A massa que os envolve possui textura predominantemente silto-argilosa de cor bruno/bruno-escuro.

Na superficie rugosa III (Figura 15), localizada em uma concavidade ampla, paralela à super- 


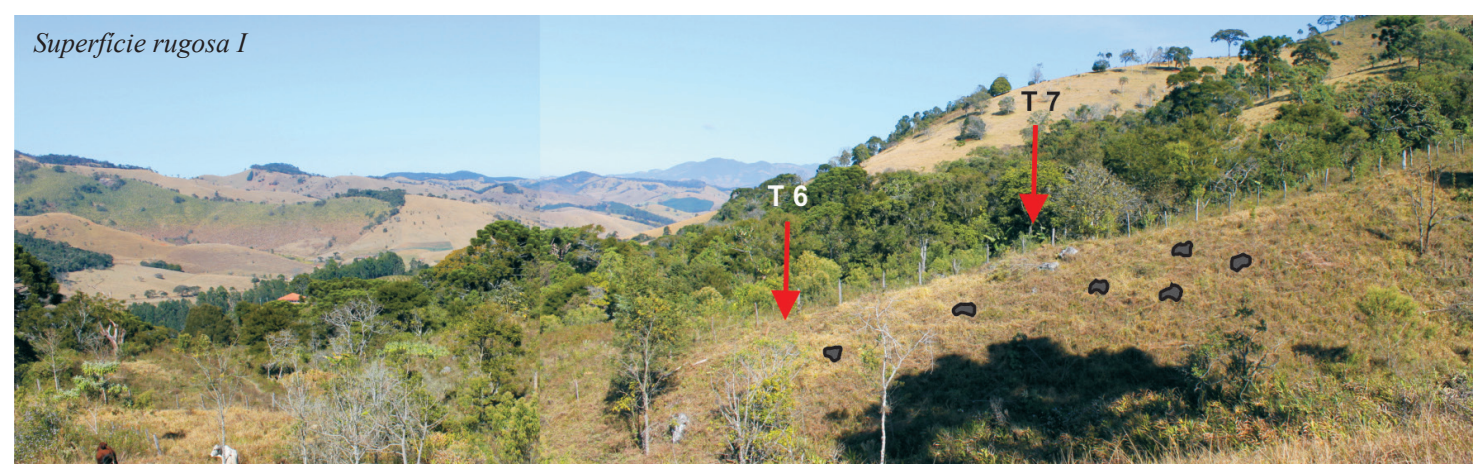

Descrição - Tradagem 6 (T6)

Descrição - Tradagem 7 (T7)

0-20 cm: Cor: bruno-avermelhado-escuro (5YR 3/3); Textura: argilo-areno-siltosa; Plástico e pegajo- $0-20 \mathrm{~cm}$ : Superfície com muitos blocos. so; Presença de areia fina e pequenos fragmentos de rocha. Pouca mica e feldspato.

20-40 cm: Cor: bruno-avermelhado (5YR 4/4); 20-70 cm: Cor: bruno-avermelhado-escuro (5YR 3/4); Textura: argilo-areno-siltosa; Plástico e pega- Textura: argilo-areno-siltosa; Pouca areia grosjoso; Presença de areia mais grossa.

sa; Presença de fragmentos de rocha. Não foi 70-90 cm: Cor: bruno-avermelhado (5YR 4/4),Textura: argilo-areno-siltosa; Plástico e pegajoso; Pre- possível tradar após $40 \mathrm{~cm}$. sença de areia mais grossa.

90-100 cm: Cor: vermelho-amarelado (5YR 4/6) com volumes mais amarelados (5YR 5/8); Material de alteração da rocha.

100-120 cm: Cor: vermelho-amarelo (5YR 5/8); Material de alteração da rocha.

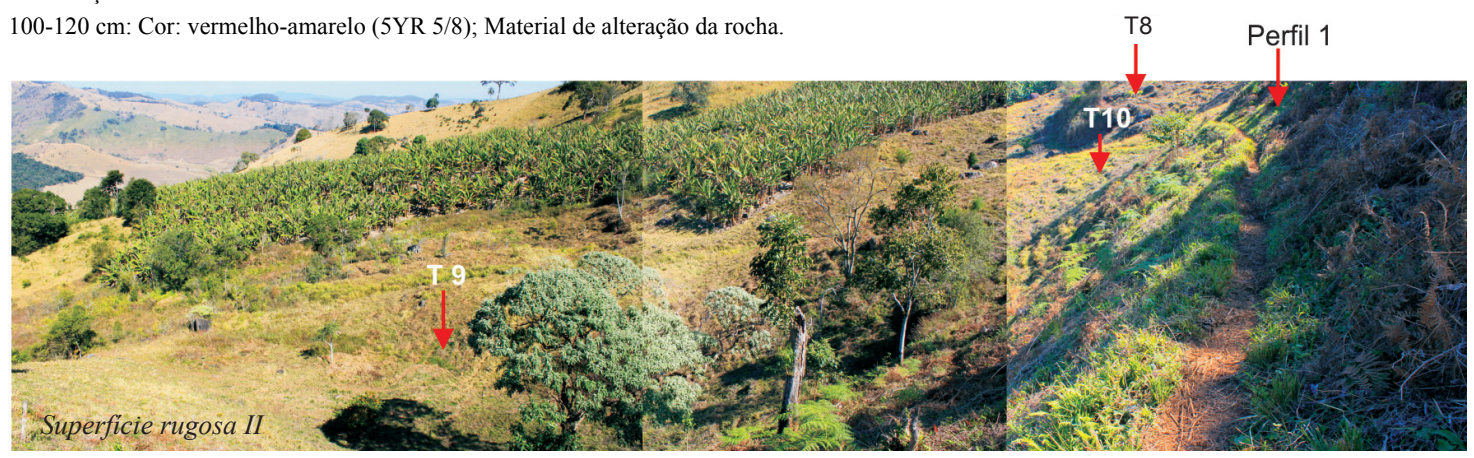

Tradagem 9 (T9)

Tradagem 10 (T10)

Tradagem 8 (T8)

0-20 cm: Cor: cinzento-muito-escuro (7,5YR 3/1); Textura: areno-argilosa. $0-40 \mathrm{~cm}$ : Cor: bruno-escuro (7,5 YR $0-20 \mathrm{~cm}$ : Cor: bruno-muito-escu20-40 cm: Cor: bruno-acinzentado-muito-escuro (10YR 3/2); Textura: are- 3/4); Textura: argilo-areno-siltosa, ro (7,5YR 2,5/3); Textura: argilono-argilosa; Predominância da fração areia média, com pouca areia grossa. com pouca mica e areia grossa; Pega- -areno-siltosa; Presença de frag40-70 cm: Cor: bruno-acinzentado-muito-escuro (10YR 3/2); Textura: areno-argilosa; Ligeiramente mais plástico, pouco pegajoso e mais úmido; Presença de fragmentos de rocha a partir dos $50 \mathrm{~cm}$

joso e plástico.

40-70 cm: Cor: bruno-avermelhado 20-40 cm: Cor: bruno-muitoescuro (5YR 3/4); Textura: argilo-sil- -escuro (7,5YR 2,5/3); Textura: tosa, com um pouco silte e areia média argilo-areno-siltosa; Presença de

$70-80 \mathrm{~cm}$ : Cor: cinzento-muito-escuro (10YR 3/1); Textura areno-argilosa; tosa, com um pouco silte e areia média cascalhos de rocha.
Presença de mineral primário, pouco de água livre e fragmentos de rocha. Presença de mineral primário, pouco de água livre e fragmentos de rocha. $80-90 \mathrm{~cm}$ : Cor: bruno-acinzentado-escuro (10YR 4/2); Textura: areno-argilosa; presença de areia média, cascalho e pouca areia grossa. Material mais seco.

terial de alteração da rocha.

Abaixo de $40 \mathrm{~cm}$ : o trado não consegue avançar e apresen-

$70-80 \mathrm{~cm}$ : Cor: vermelho-amarelo ta fragmentos de rocha em sua (5YR 4/6); Textura: argilo-siltosa,com ponta.

90-100 cm: Cor: bruno-acinzentado-escuro (10YR 4/2); Material de alte- maior presença de argila; Presença de ração com cascalhos de aproximadamente $3 \mathrm{~cm}$. material de alteração.

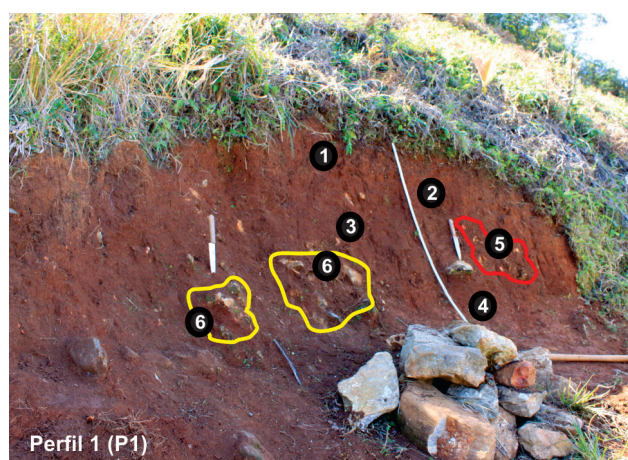

Perfil 1 (Pl):

1 [ 0-20 cm: Cor: bruno-escuro (7,5 YR 3/4); Textura: silto-argilosa.

2 0-50 cm: Cor: bruno-escuro (7,5 YR 3/4); Textura: silto-argilosa (ligeiramente mais argiloso).

3 50-100 cm: Cor: bruno (7,5 YR 4/4); Textura: silto-argilosa (ligeiramente mais argiloso).

4 100-140 cm: Cor: bruno (mais avermelhado) (7,5 YR 4/4); Textura: argilo-siltosa com areia grossa.

5 [50-90 cm: Blocos centimétricos de 2 a $5 \mathrm{~cm}$, bastante alterados, envolto em uma matriz argilo-siltosa.

6 [90-110 cm: Concentração de blocos maiores, variam entre 12 a $20 \mathrm{~cm}$, menos alterados.

Blocos de rochas bastante alterados (2 a $5 \mathrm{~cm}$ ).

Blocos de rochas menos alterados $(12 \mathrm{a} 20 \mathrm{~cm})$

FIGURA 14 - Descrição das tradagens e perfis da superfície rugosa I (T6, T7) e superfície rugosa II (T8, T9, T10, P1). Vide localização das tradagens e perfis na figura 13 e Anexo 3 (foto: R. Aranha). 


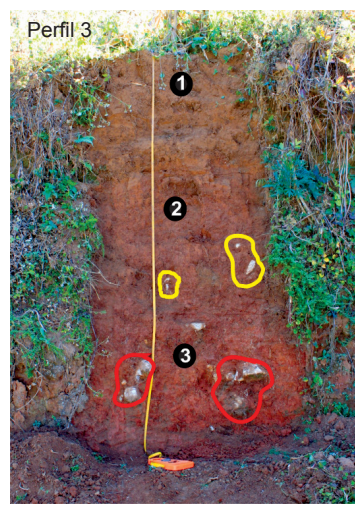

Descrição

1 0-80 cm: Cor: bruno-escuro (7,5YR 3/3); Textura: silto-argilo-arenosa (com areia fina); Plástico e pouco pegajoso; Porosidade entre os blocos; Grande presença de raízes; Material seco e friável.

2 [ 80-180 cm: Cor: bruno-escuro (7,5YR 3/3); Textura: silto-argilo-arenosa (areia fina); Plástico e pegajoso; Presença de porosidade causada pela atividade biológica; Material mais úmido; A partir de $130 \mathrm{~cm}$ aparecem blocos centimétricos (entre 3 e $12 \mathrm{~cm}$ ).

3 [ 180-240 cm: Cor: vermelho-escuro (2,5YR 3/6); Textura: silto-arenosa; Presença de porosidade causada pela atividade biológica; Material continua úmido; Apresenta blocos maiores (entre 10 e $30 \mathrm{~cm}$ ) e pequenos fragmentos de rocha.

Blocos menores $(3$ a $12 \mathrm{~cm})$.

Blocos maiores $(10$ e $30 \mathrm{~cm})$
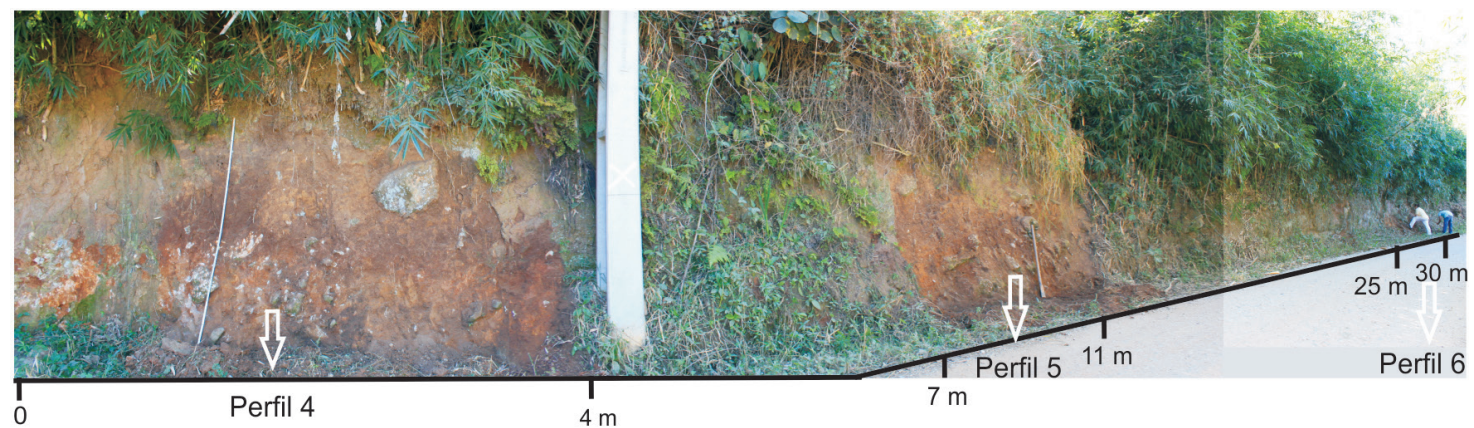

Descrição

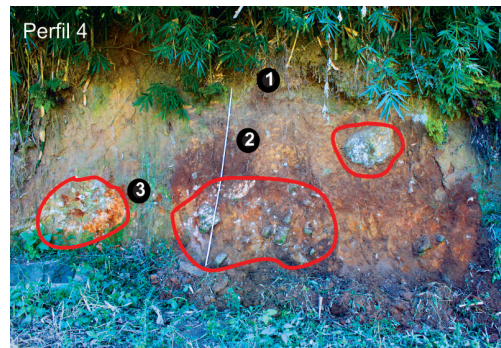

1 0-50 cm: Cor: bruno-escuro (7,5YR 3/4); Textura: silto-arenosa com presença de areia média, pouca argila; Plástico e não pegajoso; Material seco e muito friavel; Grande presença de raízes de bambus.

2 50-100 cm: Cor: bruno-escuro (7,5YR 3/3); Textura: silto-areno-argilosa com presença de areia média; Plástico e pouco pegajoso; Estrutura em blocos subangulares; Presença de blocos de rocha de vários tamanhos $(4 \mathrm{a} 30 \mathrm{~cm})$.

3 100-120 cm: Cor: vermelho-amarelo (5YR 4/6); Textura: silto-areno-argilosa com presença de areia grossa; Plástico e pouco pegajoso; Grande concentração de blocos de rocha (gnaisse) de varios tamanhos (4 a $50 \mathrm{~cm})$.

Concentração de blocos de rocha.

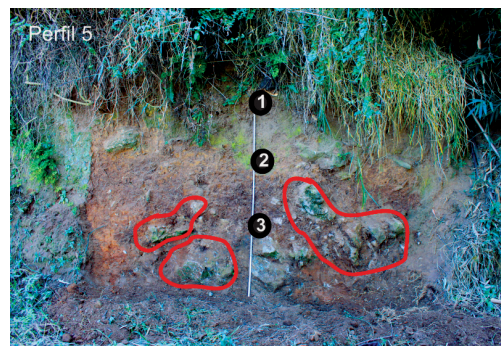

1 0-60 cm: Cor: bruno-escuro (10YR 3/3); Textura: silto-areno-argilosa com presença de areia grossa; Plástico e pouco pegajoso; Material seco; Porosidade ligada à grande presença de raízes de bambus.

2 60-100 cm: Cor: bruno-acinzentado-muito-escuro (10YR 3/2); Textura: silto-areno-argilosa; Plástico e pouco pegajoso; Presença de blocos de rocha de vários tamanhos $(10$ a $50 \mathrm{~cm})$ e raízes.

3 Abaixo de $100 \mathrm{~cm}$ : Cor: bruno-forte (7,5YR 4/6); Textura: silto-argilo-arenosa; Plástico e pegajoso; Grande concentração de blocos de rocha $(50$ a $140 \mathrm{~cm})$.

Grandes blocos de rocha $(50 \mathrm{a} 140 \mathrm{~cm})$.

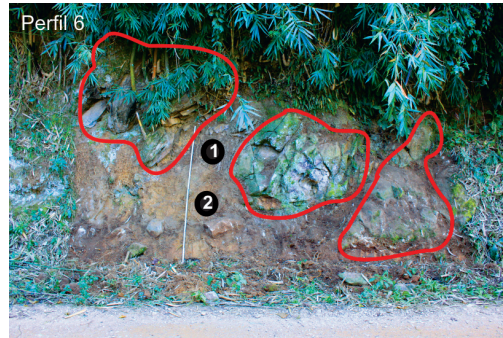

1 0-50 cm: Cor: bruno avermelhado escuro (5YR 3/4); Textura: silto-areno-argilosa com presenca de areia grossa; Plástico e pouco pegajoso; Material seco; Porosidade ligada à presença de raízes de bambus; presença de blocos de tamanhos variados $(10 \mathrm{a} 110 \mathrm{~cm})$

2 50 a $130 \mathrm{~cm}$ : Cor: bruno (7,5YR 4/4); Textura: silto-arenosa com areia grossa; Plástico; Presença de mica e de grandes blocos de rocha de tamanhos variados $(10 \mathrm{a} 110 \mathrm{~cm})$

Blocos de rocha.

FIGURA 15 - Descrição dos perfis da superfície rugosa III (P3, P4, P5, P6). Vide localização dos perfis na figura 13 e Anexo 3 (foto: R. Aranha). 
ficie rugosa II, foram descritos perfis ( $\mathrm{P} 3, \mathrm{P} 4, \mathrm{P} 5$ e P6) expostos ao longo da estrada que liga o bairro Baú do Centro ao Monjolinho, que seccionam esta forma no sentido transversal.

De uma maneira geral, predominam nesses perfis materiais de textura silto-areno-argilosa e silto-argilo-arenosa, de cor bruno/bruno escuro, com presença de blocos que variam de centimétricos a métricos, e porosidade relacionada a grande presença de raízes e atividade biológica.

\subsubsection{Cicatrizes com patamar}

Nas cicatrizes com patamar a análise dos materiais foi realizada a partir de tradagens (T1, T2, T3, T11 e T12) localizadas, preferencialmente, no centro da forma ou ao longo do eixo mais rebaixado.

A cicatriz com patamar I (Figura 16) localiza-se em um interflúvio secundário de topo convexo e possui um eixo bem nítido entre o patamar e a encosta.
Nesta cicatriz foram realizadas três tradagens (T1, T2 e T3) com profundidade média de $150 \mathrm{~cm}$, onde foram encontrados materiais bem desenvolvidos, homogêneos, predominantemente na cor bruno/bruno escuro, com textura variando de silto-argilosa a argilo-siltosa (Figura 16).

As cicatrizes com patamar II e III (Figura 16) apresentaram materiais semelhantes aos encontrados na cicatriz com patamar I, destacando apenas a presença de pacotes orgânicos pouco espessos e sinais de hidromorfia.

\subsubsection{Depressão}

A única feição de depressão analisada do ponto de vista morfológico (Figura 17) localiza-se em posição altimétrica inferior a todas outras formas analisadas, delimitada por encostas de declividade acentuadas e possui forma circular, não apresentando conectividade com a drenagem perene ou intermitente.

Apresentou materiais com características semelhantes às observadas nas cicatrizes com pata-

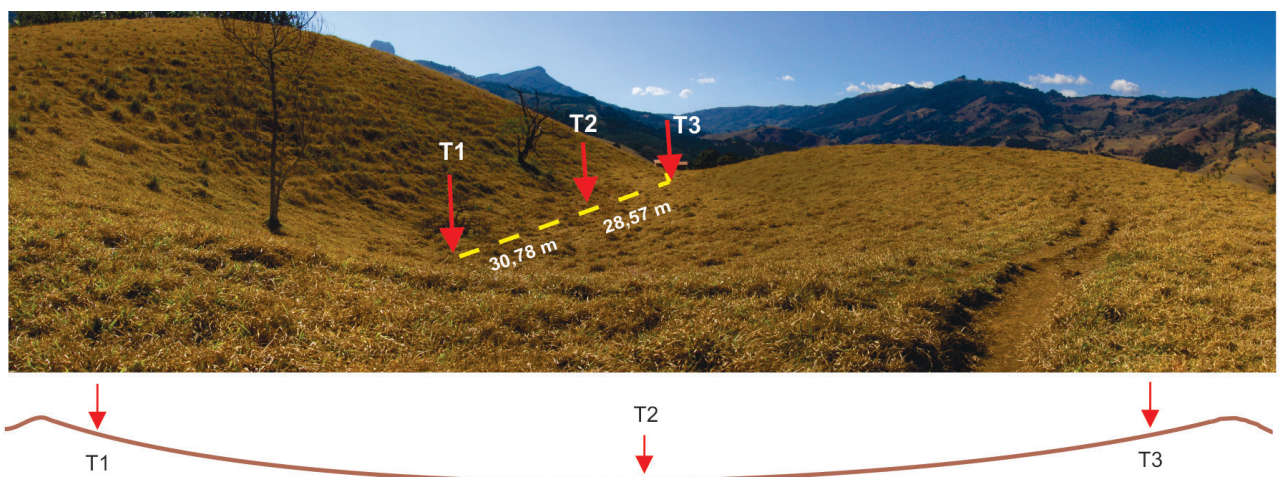

Descrição - Tradagem 1 (T1)

0-40 cm: Cor: bruno-escuro (7,5YR 3/3); Textura: silto-argilosa; Presença de fragmentos de quartzo e carvão e a partir de $30 \mathrm{~cm}$ aparecem volumes mais amarelados (transição).

40-90 cm: Cor: bruno-avermelhado (5YR 4/4); Textura: argilo-siltosa; Pegajoso; Plástico; Presença de grãos de quartzo.

90-110 cm: Cor: bruno-avermelhado (5YR 4/4), com presença de volumes amarelos e vermelhos; Textura: argilo-siltosa.

110-130 cm: Cor: bruno-forte (7,5YR 4/6), ligeiramente mais amarelo; Textura: argilosiltosa, com mais argila; Presença de fragmentos de rocha alterada a partir de $120 \mathrm{~cm}$.

130-140 cm: Cor: bruno-forte (7,5YR 5/8); Textura: argilo-siltosa; Transição para material de alteração da rocha.

140-150 cm: Material de alteração da rocha.
Descrição - Tradagem 2 (T2)

0-20 cm: Material contaminado.

20-40 cm: Cor: bruno-escuro (7,5YR 3/2); Textura: silto-argilosa; Pouco pegajoso; Não plástico; Presença de grãos de quartzo e de volumes amarelos a partir de $30 \mathrm{~cm}$.

40-50 cm: Cor: bruno (7,5YR 4/4); Textura: silto-argilosa.

50-70 cm: Cor: bruno (7,5YR 4/4) e volumes avermelhados; Textura: argilo-siltosa.

70-100 cm: Cor: bruno-muito-escuro (7,5YR 2,5/2); Textura: argilo-siltosa.

100-120 cm: Cor: bruno-avermelhado (5YR 4/4); Textura: argilo-siltosa; Material mais úmido.

120-140 cm: Cor: vermelho-amarelo (5YR 4/6); Textura: argilo-siltosa; A partir de $130 \mathrm{~cm}$ presença de rocha alterada.

140-160 cm: Cor: vermelho-amarelo (5YR 5/8); Textura: argilo-siltosa; Na ponta do trado com material mais seco na cor amarela; Presença de fragmentos de mica e quartzo.
Descrição - Tradagem 3 (T3)

0-30 cm: Cor: bruno-claro.

30-40 cm: Cor: vermelho-amarelo; Textura: silto-argilosa; Material mais seco.

40-100 cm: Cor: bruno-escuro (7,5YR 3/4); Textura: silto-argilosa; Material mais úmido; Homogeneidade do material. 100-150 cm: Cor: bruno-avermelhado escuro (5YR 3/4) (massa predominante) com volumes de cor bruno-escuro (7,5YR 3/4); Textura: silto-argilosa; Presença de bandamento da rocha, rica em minerais ferro-magnesianos; Material de alteração da rocha.

FIGURA 16 - Descrição das tradagens na cicatriz de patamar I (T1, T2, T3). Vide localização das tradagens na figura 13 e Anexo 3 (foto: Marcos Pinheiro). 

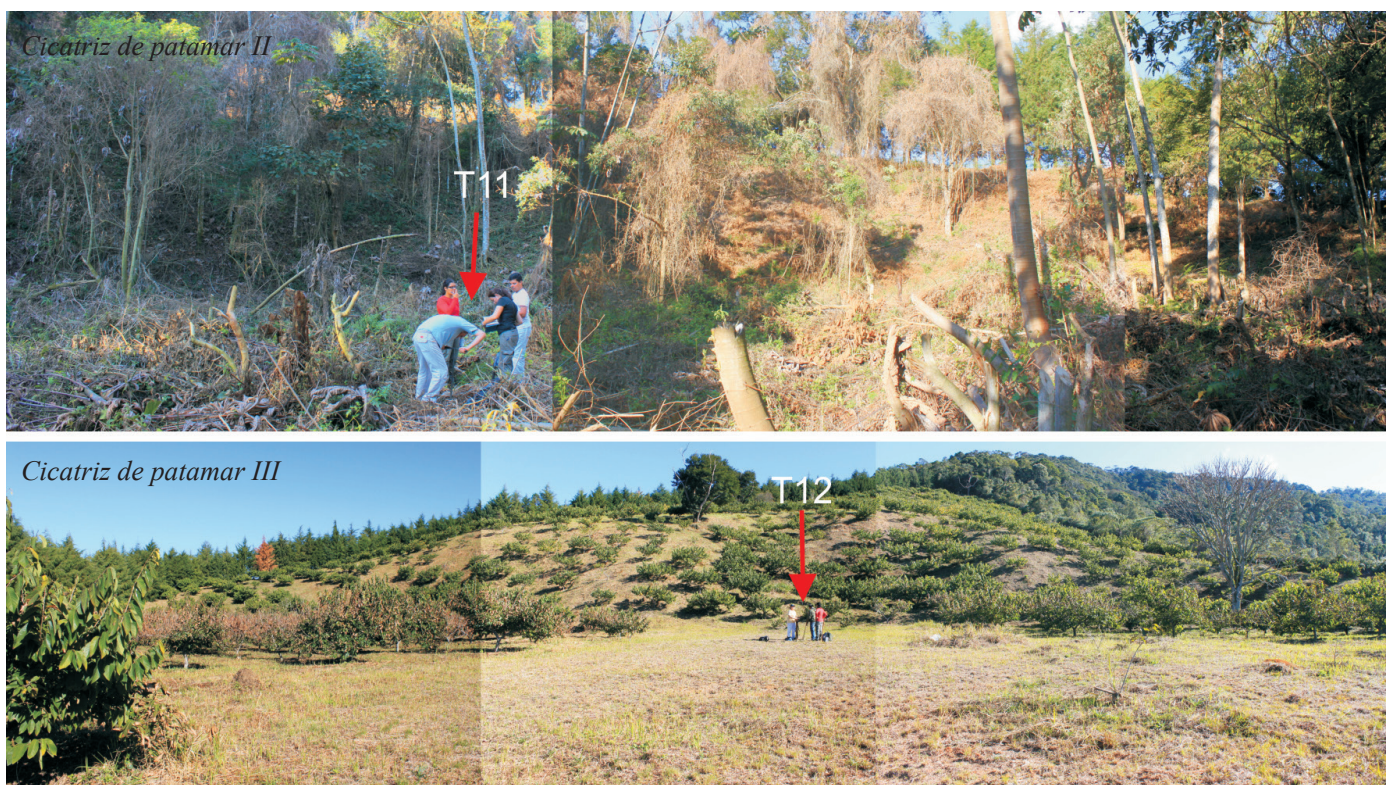

Descrição - Tradagem 11 (T11)

0-30 cm: Cor: bruno-escuro (7,5YR 3/2) com volumes de cor cinzento-vermelhado-escuro (2,5Y 3/1); Textura: argilo-siltosa com pouca areia média; Pegajoso.

30-60 cm: Cor: bruno-escuro (7,5YR 3/2); Textura: argilo-siltosa; Pegajoso; Presença de pequenos volumes vermelhos (oxidação) que vão diminuindo a partir de $40 \mathrm{~cm}$.

60-80 cm: Cor: bruno-muito-escuro (10YR 2/2); Textura: argilo-arenosa com presença de areia média; Pouco pegajoso e ligeiramente plástico.

80-100 cm: Cor: bruno-escuro (10YR 3/3); Textura: argilo-silto-arenosa.

100-140 cm: Cor: preto (10YR 2/1), passando a $120 \mathrm{~cm}$ para bruno-muito-escuro (10YR 2/2); Textura: argilo-siltosa com pouca areia média; Material mais escuro, mais úmido com provável presença de matéria orgânica.

140-180 cm: Cor: bruno-escuro (7,5YR 3/2); Textura: argilo-silto-arenosa; Plástico e pegajoso; transição do pacote orgânico para um material mais pedogeneizado; a partir de $160 \mathrm{~cm}$ aparecem pequenos volumes amarelados na ponta do trado $(180 \mathrm{~cm})$ aparece um material mais avermelhado. 180-190 cm: Cor: bruno-escuro (7,5YR 3/3); Textura: argilo-silto-arenosa, mais argiloso; Plástico e pegajoso.

FIGURA 16 - (cont.) Descrição das tradagens nas cicatrizes de patamar II (T11) e III (T12). Vide localização das tradagens na figura 13 e Anexo 3 (fotos: R. Aranha).

mar (I, II e III), com predominância da textura silto-argilosa, cores bruno/bruno forte e sinais de hidromorfia, mesmo em período de estiagem.

\section{CONSIDERAÇÕES SOBRE A GÊNESE DAS SUPERFÍCIES RUGOSAS, CICATRIZES COM PATAMAR E DEPRESSÕES}

Os mapeamentos morfológicos realizados na bacia do ribeirão do Baú (1:10.000 e 1:50.000) e as observações de campo, permitiram, com apoio da bibliografia, traçar modelos de evolução preliminares das feições caracterizadas como superfícies rugosas, cicatrizes com patamar e depressões

No caso das superfícies rugosas, buscou-se apoio em MODENESI (1988) MARUJO (1994) e HIRUMA \& TEIXEIRA (2013), que desenvolveram pesquisas na mesma região, em sistemas morfogenéticos equivalentes ou próximos.

MODENESI (1988) mostrou que no Planalto de Campos do Jordão as vertentes evoluíram por processos de movimentos de massa durante o Pleistoceno, testemunhados por, pelo menos, três 


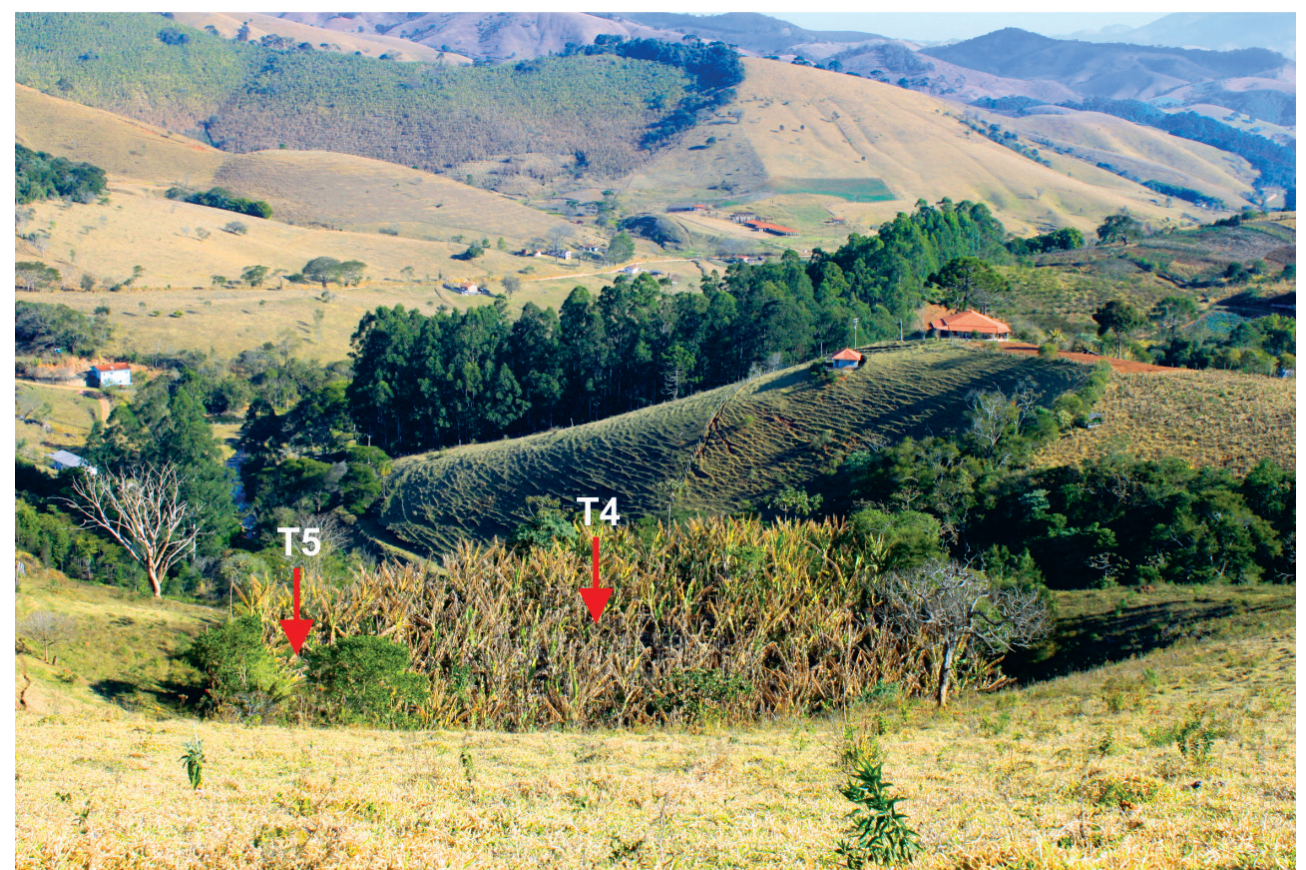

Descrição - Tradagem 5 (T5)

0-50 cm: Cor: bruno-avermelhado-escuro (5YR 3/3); Textura: silto-areno-argilosa; Material bastante solto, friável de aspecto microagregado, com bastante mineral primário.

50-100 cm: Cor: bruno-escuro (7,5YR 3/4); Textura: silto-argilosa; Plástico e pegajoso.

100-110 cm: Cor: bruno-muito-escuro (7,5YR 3/4); Textura: silto-argilosa; Plástico e pegajoso.

110-150 cm: Cor bastante heterogênea, sendo a massa do material na cor cinzento-muito-escuro (5YR 3/1), com volumes de cor bruno avermelhado escuro; Textura: argilo-siltosa.

150-160 cm: Cor: bruno-forte (7,5YR 4/6); Textura: argilo-siltosa; Aparência de material de alteração da rocha.
Descrição - Tradagem 4 (T4)

0-40 cm: Cor: bruno-escuro (7,5YR 3/3); Textura: silto-argilo-arenosa; com aumento da profundidade o material torna-se ligeiramente mais argiloso; Material seco.

40-120 cm: Cor: bruno-forte (7,5YR 4/6); Textura: silto-argilosa; Muito plástico, pouco pegajoso; a partir de $70 \mathrm{~cm}$ o material fica ligeiramente mais úmido; Presença da aspereza da fração areia desde o início, diminuindo a partir de $100 \mathrm{~cm}$.

120-130 cm: Cor: bruno (7,5YR 4/2), com volumes de cor oliva claro acinzentado (5Y 6/3); Textura: silto-argilosa; Hidromorfia (?).

130-140 cm: Cor: oliva-claro-acinzentado (5Y 6/3) com volumes de cor bruno-forte (7,5YR 5/6); Textura: argilo-siltosa; Presença de material de alteração da rocha no nível da hidromorfia.

140-150 cm: Cor: bruno-forte (7,5YR 5/8); Textura: argilo-siltosa com presença de areia grossa; Material de alteração da rocha com fragmentos milimétricos de quartzo e feldspato.

FIGURA 17 - Descrição das tradagens na depressão (T4, T5). Vide localização das tradagens na figura 13 e Anexo 3 (foto: R. Aranha).

gerações de anfiteatros de erosão. Vertentes com espessos depósitos de tálus e colúvios, suspensos e superpostos, compostos por materiais mal selecionados, semelhantes às das superfícies rugosas, foram interpretados como testemunhos de diversos episódios de movimentos de massa (MODENESI 1988, MARUJO 1994, BIGARELLA 2003, HIRUMA \& TEIXEIRA 2013). MARUJO (1994), em seu estudo morfológico da bacia do rio Santa Bárbara, localizada nas escarpas do Planalto de Campos do Jordão, próximo a bacia do ribeirão do Baú, observou também a presença de blocos e matacões espalhados nos setores mais baixos da superfície; essas superfícies cobertas por blocos foram mapeadas e associadas à presença de rochas charnoquíticas e de zonas cataclásticas, que favoreceram o intemperismo e a desagregação das rochas em blocos angulares.
A concentração desse material rudáceo em superfície pode ocorrer em função do escoamento difuso superficial ou pelo escoamento concentrado sobre o depósito, removendo os detritos mais finos e expondo o material mais grosseiro e heterométrico.

As observações feitas em fotos aéreas de escala de detalhe e em campo mostraram que uma rede de canais de escoamento, na forma de sulcos de traçado anastomosado, com zonas de concentração e dispersão do fluxo, em função dos obstáculos rochosos encontrados, é responsável pelo aspecto rugoso, tão nítido nas fotografias aéreas em diversas escalas. A figura 18 ilustra uma proposta para o modelo evolutivo das superfícies rugosas na área de estudo.

Com relação às concavidades nas vertentes, que podem ou não conter patamares internos e es- 

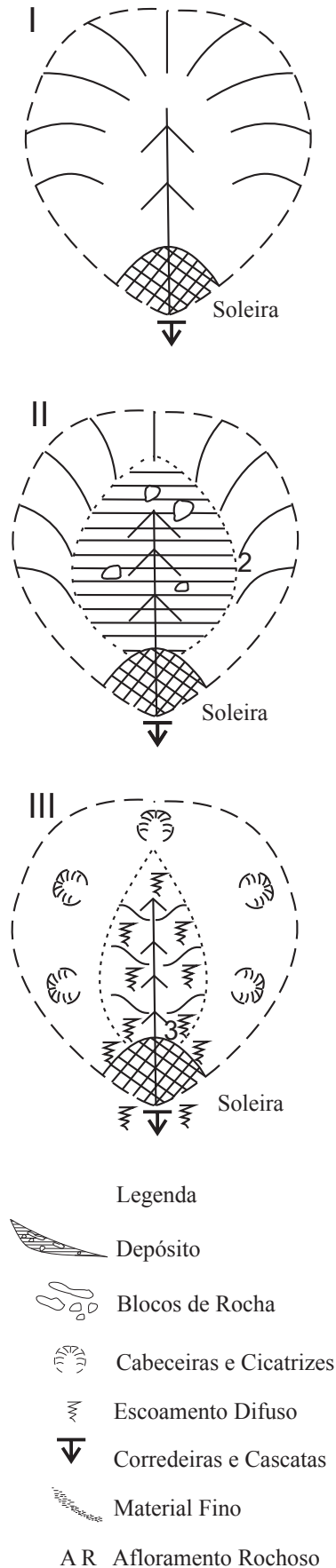

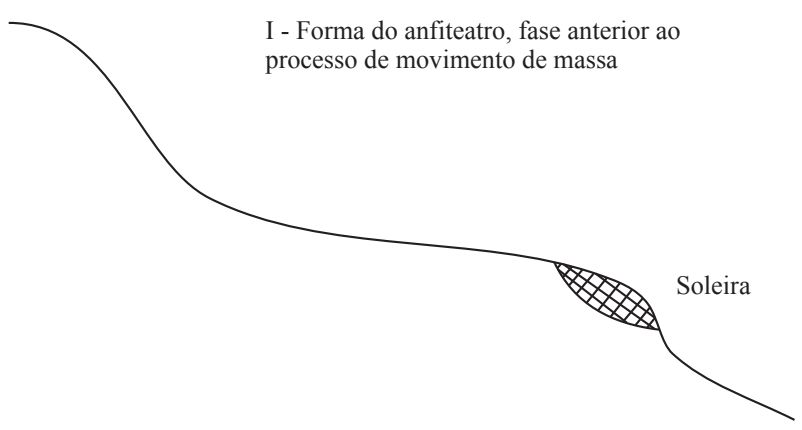

II - Movimento de massa com reafeiçoamento da forma, apresentando superfície de ruptura bem marcada, com exposição da rocha e acúmulo de material grosso (depósito) no interior do anfiteatro "soterrando" o eixo da drenagem e formando patamares

FIGURA 18 - Modelo evolutivo das superfícies rugosas (desenho de Daniela Beato).

tar ou não conectadas a canais de escoamento superficiais e efêmeros, buscou-se apoio em pesquisas realizadas por FILIZOLA \& BOULET (1993, 1996), BIGARELLA (2003) e COELHO NETO (2003).

FILIZOLA \& BOULET (1993, 1996), estudando depressões fechadas sobre rochas sedimen- tares quartzo-caoliníticas, no Vale do Paraíba, estimaram a velocidade da erosão geoquímica na gênese e evolução dessas depressões.

COELHO NETO (2003), estudando a formação e crescimento de canais em cabeceiras de drenagem, na região do médio vale do Paraíba do Sul, estabeleceu, além de uma tipologia, esquemas 
evolutivos das concavidades estruturais e depressões. A autora destacou a importância dos sistemas de falhas do maciço rochoso no desenvolvimento dessas feições, por favorecerem a perda vertical da água e, consequentemente, a denudação geoquímica, levando ao rebaixamento do fundo do vale principal e do nível do lençol freático, responsável pela estabilização morfodinâmica das concavidades. Quando suspensas, desconectadas da rede de canais, as concavidades e depressões podem ser consideradas como formas-relíquias.

A análise dessas observações, correlacionada com as características morfográficas e morfológicas, suscitaram questionamentos sobre a origem e os processos envolvidos na gênese dessas feições. A figura 19 esquematiza de forma preliminar um modelo evolutivo das depressões e cicatrizes com patamar.

\section{CONCLUSÕES}

A bacia do ribeirão do Baú corresponde à uma frente de dissecação do Planalto de Campos do Jordão, sendo responsável, junto com outros afluentes da margem direita do Rio Sapucaí-
Mirim, pelo festonamento da escarpa sudoeste deste planalto e pela sua individualização em relação ao Planalto de Camanducaia.

A legenda morfológica utilizada no mapeamento morfológico da bacia do ribeirão do Baú (1:50.000) procurou agrupar e relacionar as suas representações a processos genéticos, a partir das características morfográficas, e permitiu o estabelecimento dos compartimentos morfológicos. Vale ressaltar que, de uma maneira geral, as cartas geomorfológicas são representações de difícil leitura. Sendo assim, buscou-se produzir uma legenda ilustrativa, utilizando-se de fotografias de paisagem, fotografias aéreas e perfis esquemáticos, visando buscar sua melhor compreensão.

A bacia apresenta forte controle estrutural, evidenciado pela presença de interflúvios escarpados e em forma de crista, facetas triangulares e trapezoidais, além de anomalias de drenagem, que sugerem controle neotectônico.

Embora apresente uma grande diversidade morfológica, algumas formas e feições do relevo destacaram-se na paisagem, pela magnitude e frequência com que ocorrem (superfícies rugosas) e pela singularidade (depressões e concavidades

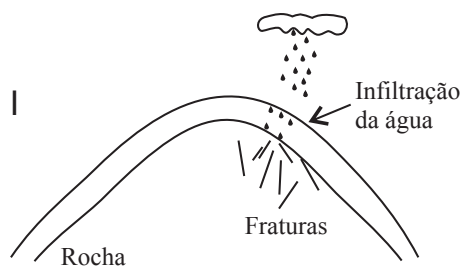

I- Sistemas de falhas e fraturas favorecem a infiltração da água da chuva

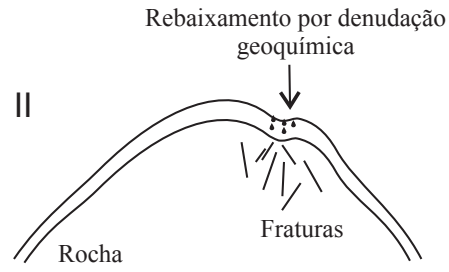

II e III - A água infiltra pelas fraturas favorecendo a exportação de solutos (lixiviação) e o progressivo rebaixamento desta paisagem até a formação da depressão

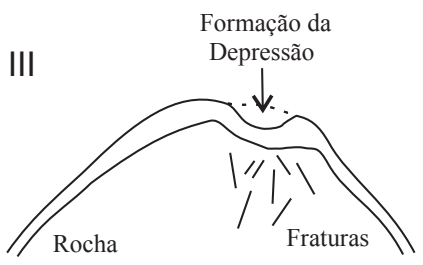

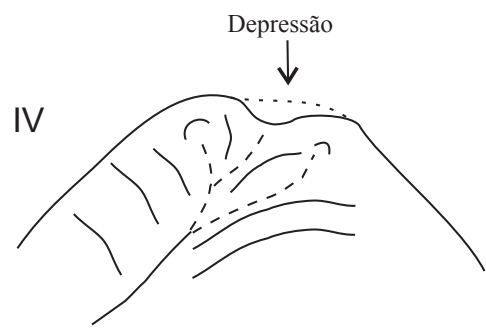

IV - A depressão pode sofrer rebaixamento de uma de suas encostas, transformando-se em concavidades com patamar

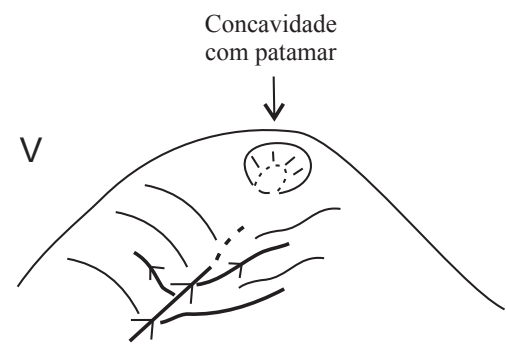

$\mathrm{V}$ - Com o rebaixamento do fundo do vale e a diminuição do nível do lençol, essas concavidades com patamar ficam suspensas

FIGURA 19 - Modelo evolutivo da depressão e da cicatriz com patamar (desenho de Daniela Beato). 
com patamar). Estas formas, que se assemelham às descritas em regiões próximas da área de estudo, indicam a necessidade de um estudo em escala de maior detalhe, tanto morfológico, quanto dos seus materiais, com a elaboração de topossequências, de forma a buscar comprovações sobre a gênese do relevo da bacia do ribeirão do Baú.

\section{AGRADECIMENTOS}

As autoras agradecem os relatores da Revista do Instituto Geológico pelas sugestões que enriqueceram o trabalho e ao Programa de PósGraduação em Geografia Física do Departamento de Geografia/FFLCH/USP pelo suporte na realização do Mestrado da autora principal, sob a orientação da Profa. Dra. Rosely Pacheco Dias Ferreira, do qual este artigo é derivado.

\section{REFERÊNCIAS BIBLIOGRÁFICAS}

ALMEIDA, F.F.M. 2018 [1964]. Fundamentos geológicos do relevo paulista. Revista do Instituto Geológico, 39(3): 9-75. Republicado de Boletim do Instituto Geográfico e Geológico, número 41 (p. 169-263), 1964. https://doi. org/10.33958/revig.v39i3.600

ALMEIDA, F.F.M.; CARNEIRO, C.D.R. 1998. Origem e evolução da Serra do Mar. Revista Brasileira de Geociências, 28(2): 135-150. http://dx.doi.org/10.25249/03757536.1998135150

BIGARELLA, J.J. 2003. Estrutura e origem das paisagens tropicais e subtropicais. Ed. da UFSC, Florianópolis, 3 v.

BRITO NEVES, B.B.; FUCK, R.A.; PIMENTEL, M.M. 2014. The Brasiliano collage in South America: a review. Brazilian Journal of Geology, 44(3): 493-518. http://dx.doi. org/10.5327/Z2317-4889201400030010

COELHO NETTO, A.L. 2003. Evolução de cabeceiras de drenagem no médio vale do Rio Paraíba do Sul (SP/RJ): a formação e o crescimento da rede de canais sob controle estrutural. Revista Brasileira de Geomorfologia, 4(2): 69-100. http://dx.doi.org/10.20502/rbg. v4i2.25

COOKE, R.U.; DOORNKAMP, J.C. 1990. Geomorphology in environmental management: a new introduction. Oxford University Press, Oxford, $2^{\text {nd }}$ ed., $410 \mathrm{p}$.

DEMEK, J. 1967. Generalization of geomorphological maps. In: Progress made in geomorphological mapping. Zpravy o vedeckych vyzkumech, 9: 36-72.

DEMEK, J. 1972. Manual of detailed geomorphological mapping. Praga, Academia.

DONÉ, S.S.B. 1981. Mapas geomorfológicos e suas legendas: uma contribuição para estudos analíticos. Notícia Geomorfológica, 21: $85-110$.

FILIZOLA, H.; BOULET, R. 1993. An evaluation of rate of erosion from study of closed depression on sedimentary kaolinitic rocks in Brazil. Comptes Rendus - Academie des Sciences, Serie II, 693-700.

FILIZOLA, H.F.; BOULET, R. 1996. Evolution and opening of closed depressions developed in a quartz-kaolinitic sedimentary substratum at Taubaté basin (São Paulo, Brazil), and analogy to the slope evolution. Geomorphology, 16(1): 77-86. https://doi. org/10.1016/0169-555X(95)00086-K

FURQUIM, S.A.C. 1997. Estudo morfopedológico do setor centro-norte do interflúvio entre os ribeirões Samambaia e Araquá, em São Pedro, SP. Faculdade de Filosofia, Letras e Ciências Humanas, Departamento de Geografia, Universidade de São Paulo, São Paulo, Trabalho de Graduação Individual, 95 p.

HIRUMA, S.T.; TEIXEIRA, A.L. 2013. Pedra do Baú, São Bento do Sapucaí, SP - Imponente paisagem e registro de eventos tectônicos $e$ denudacionais pós-ruptura continental. In: M. Winge, C. Schobbenhaus, C.R.G. Souza, A.C.S. Fernandes, M. Berbert-Born, W. Sallun Filho, E.T. Queiroz (Eds.) Sítios Geológicos e Paleontológicos do Brasil, v. 3, p. 39-56.

HIRUMA, S.T.; RICCOMINI, C.; MODENESI-GAUTTIERI, M.C. 2001. Neotectônica no Planalto de Campos do Jordão, SP. Revista Brasileira de Geociências, 31(3): 347-356. https://doi.org/10.25249/03757536.2001313375384 
IAC - INSTITUTO AGRONÔMICO DE CAMPINAS. 1999. Mapa pedológico do Estado de São Paulo - Escala 1:500.000. EMBRAPA/ IAC, São Paulo, 1 mapa em 4 folhas, colorido.

MARUJO, M.F. 1994. Estudo morfológico de uma bacia de drenagem nas escarpas do Planalto de Campos do Jordão, Serra da Mantiqueira, $S P$. Faculdade de Filosofia, Letras e Ciências Humanas, Universidade de São Paulo, São Paulo, Dissertação de Mestrado, 146 p.

MEIS, M.R.M.; MONTEIRO, A.M.F. 1979. Upper Quaternary rampas: Doce river valley, Southeastern Brazilian plateau. Zeitschrift für Geomorphologie, 23(2): 132-151.

MODENESI, M.C. 1988. Significado dos depósitos correlativos quaternários em Campos do Jordão - São Paulo: implicações paleoclimáticas e paleoecológicas. São Paulo: Instituto Geológico, 155 p. (Boletim, 7).

QUEIROZ NETO, J.P.; JOURNAUX, A. (Orgs.). 1978. Estudo e cartografia de formações superficiais e suas aplicações em regiões tropicais. Colóquio Interdisciplinar Franco-Brasileiro. Universidade de São Paulo, Faculdade de Filosofia, Letras e Ciências Humanas, Departamento de Geografia, São Paulo, v. 1.

RICCI, M.; PETRI, S. 1965. Princípios de aerofotogrametria e interpretação geológica. Cia. Editora Nacional, São Paulo, 226 p.
RICCOMINI, C.; SANT’ANNA, L.G.; FERRARI, A.L. 2004. Evolução geológica do Rift Continental do Sudeste do Brasil. In: V. Mantesso Neto, A. Bartorelli, C.D.R. Carneiro, Neves, B.B.B. (Eds.) Geologia do Continente Sul-Americano: Evolução da Obra de Fernando Flávio Marques de Almeida. Beca, São Paulo, p. 383-405.

ROSS, J.L.S.; MOROZ, I.C. 1997. Mapa Geomorfológico do Estado de São Paulo, escala 1:500.000. FFLCH/USP, São Paulo, 1 mapa em 2 folhas, colorido.

ROSSI, M. 2017. Mapa pedológico do Estado de São Paulo: revisado e ampliado. Secretaria do Meio Ambiente, Instituto Florestal, São Paulo, 118 p., mapas, colorido.

SAVIGEAR, R.A.G. 1965. A technique of morphological mapping. Annals of the Association of American Geographers, 55(3): 514-538. https:/doi. org/10.1111/j.1467-8306.1965.tb00532.x

TRICART, J. 1965. Principes et méthodes de la geomorphologie. Masson, Paris, 496 p.

TRICART, J. 1972. Normes pour'établissement de la carte géomorphologique détailée de la France $(1 / 20.000,1 / 25.000,1 / 50.000)$. Mémoires et documents - Centre National de la Recherche Scientifique, 12: 37-105.

\section{Endereço das autoras:}

Rosana Aranha - Rua Carmine Mazzulo, 146, Presidente Medice, CEP 13310-120, Itu, SP, Brasil. Programa de Pós-Graduação em Geografia Física, Departamento de Geografia, Faculdade de Filosofia, Letras e Ciências Humanas, Universidade de São Paulo. E-mail: rosanaaranha@prof.educacao.sp.gov.br

Rosely Pacheco Dias Ferreira - Departamento de Geografia, Faculdade de Filosofia, Letras e Ciências Humanas, Universidade de São Paulo, Avenida Lineu Prestes, 338, CEP 05508-080, Cidade Universitária, São Paulo, SP, Brasil.E-mail: rpfdias@usp.br

Artigo submetido em 15 de março de 2020, aceito em 29 de abril de 2020. 